\title{
Habitat-forming cold-water corals show affinity for seamounts in the New Zealand region
}

\author{
Dianne M. Tracey ${ }^{1, *}$, Ashley A. Rowden ${ }^{1}$, Kevin A. Mackay ${ }^{1}$, Tanya Compton ${ }^{2}$ \\ ${ }^{1}$ National Institute of Water and Atmospheric Research, Wellington, New Zealand \\ ${ }^{2}$ National Institute of Water and Atmospheric Research, Hamilton, New Zealand
}

ABSTRACT: Determining the distribution of habitatforming scleractinian corals in the New Zealand region is necessary in order to understand the ecological significance of these taxa and the likely impact of anthropogenic activities on their persistence. Historical records from early publications, research trawl surveys, commercial fishing bycatch and recent biodiversity surveys were compiled for the habitat-forming coral species Madrepora oculata, Solenosmilia variabilis, Goniocorella dumosa, Enallopsammia rostrata and Oculina virgosa. These data were used to describe the observed depth, geographic distribution and geomorphic habitat associations of the study corals in the region. A boosted regression trees analysis was also used to identify which of 11 environmental variables best describe the distribution of the 5 species across the New Zealand region, and to predict their spatial distribution. The contribution of the environmental variables differed greatly between species, but consistently identified depth and seamount occurrence as important factors describing observed coral species distribution. The models identified that $M$. oculata, S. variabilis and E. rostrata occurred in deep waters $(>1000 \mathrm{~m})$ where seabed slopes were steep, tidal current and orbital velocities were slow, sea surface primary productivity was low, and where seamounts were generally present. By contrast, G. dumosa and O. virgosa were found in relatively shallower waters, where sea surface primary productivity was high and tidal current speeds were generally fast. Spatial predictions were consistent with the recorded observations and identified that all species, apart from $O$. virgosa, were distributed throughout the region and were found primarily between $\sim 200$ and $2000 \mathrm{~m}$.

KEY WORDS: Deep sea - Scleractinia - Stony corals · Cold-water corals - Distribution · Habitat · Predictive modelling $\cdot$ New Zealand

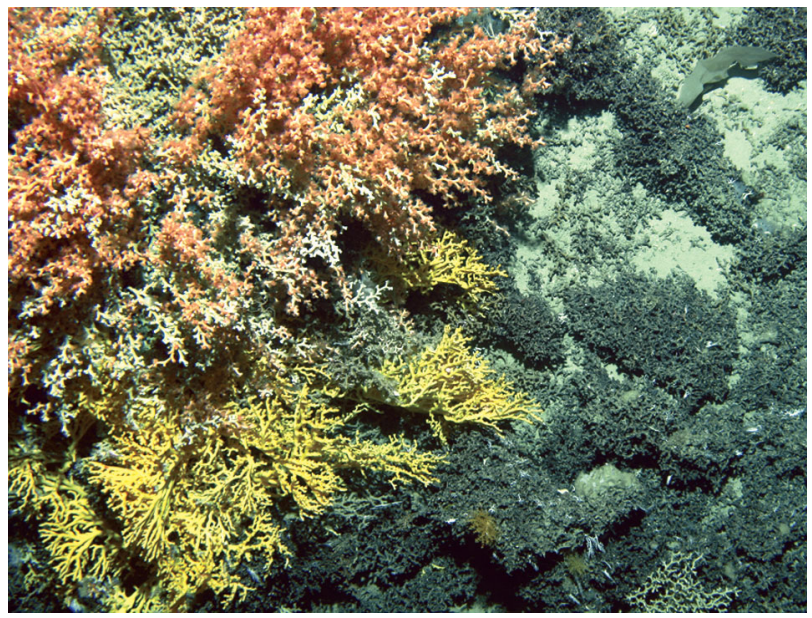

Sea floor dominated by habitat-forming stony corals Solenosmilia variabilis (upper left) and Madrepora oculata (lower left) on a seamount off New Zealand.

Image: NIWA

\section{INTRODUCTION}

Globally, cold-water corals are found most commonly between $\sim 200$ and $2000 \mathrm{~m}$ water depth and at temperatures between 4 and $12^{\circ} \mathrm{C}$ (Freiwald et al. 2004). More than 10000 described species of coldwater corals are known worldwide, and several of the groups can provide habitat for, or are known to be associated with, some species of fish and invertebrates (McCloskey 1970, Jensen \& Frederiksen 1992, Husebø et al. 2002, Jonsson et al. 2004, Buhl-Mortensen \& Mortensen 2005, Costello et al. 2005, Stone 2006, Henry \& Roberts 2007, Moore et al. 2008, Mortensen et al. 2008, D'Onghia et al. 2010, Mastrototaro et al. 2010). Some scleractinian or stony coral species produce 3-dimensional matrix colonies that can form 
'reef', 'mound' or 'thicket' structures and often provide biogenic habitat on slope margins, ridges and seamounts (Mortenson et al. 2001, Auster et al. 2005, Rogers et al. 2007, Wheeler et al. 2007, Reveillaud et al. 2008 , Roberts et al. 2008). Some reef structures can be large; for example, the Sula Ridge Lophelia pertusa coral reef off the Norwegian coast is $14 \mathrm{~km}$ long and up to $35 \mathrm{~m}$ in height (Huehnerbach et al. 2007). Stony corals can be slow-growing, long-lived (Adkins et al. 2004) and vulnerable organisms, particularly on seamounts, which are often the target of bottom trawling because of the high concentrations of fish (Rogers 1999, Clark \& Tittensor 2010). The effect of fishing impacts on cold-water corals has been well established (Koslow et al. 2001, Fossa et al. 2002, Hall-Spencer et al. 2002, Reed et al. 2007, Waller et al. 2007, Althaus et al. 2009, Clark \& Rowden 2009), and some impacts from oil and gas exploration and extraction (Gass \& Roberts 2006), the laying of cables and telecommunications links, and waste disposal (Kogan et al. 2003) have also been documented. A more recent anthropogenic threat of increasing global significance is that of decreased calcification rates in cold-water corals due to ocean acidification, which is predicted to affect their distribution (Caldeira \& Wickett 2003, Guinotte et al. 2006, Turley et al. 2007, Maier et al. 2009, Tittensor et al. 2010).

Awareness of the threats to cold-water corals has grown rapidly (Roberts \& Hirshfield 2004, Roberts et al. 2006), and understanding the ecosystem role, function and value of this important group, and the associated fauna, has become a priority in those regions where habitat-forming stony corals are particularly common, for example, around New Zealand (Consalvey et al. 2006, Rogers et al. 2007, Hourigan et al. 2008). In particular, a good understanding of the distribution of the major cold-water coral species in a particular region or the entire seafloor jurisdiction of a country (e.g. NE Pacific and USA; Heifetz 2002, Etnoyer \& Morgan 2005, Lumsden et al. 2007) is desirable in order to understand the present and possible future impacts of anthropogenic activities on these corals and, thus, implement management strategies to prevent or mitigate such impacts. Cold-water scleractinian corals have a cosmopolitan distribution, and worldwide there are 711 species (Roberts et al. 2009), of which $16.4 \%$ are found in the New Zealand exclusive economic zone (Cairns 2007). The branching framework-building species make up $26 \%$ of the scleractinian corals, with the remaining $74 \%$ representing solitary species known as cup corals (Cairns 2007). Deepwater stony corals, including habitat-forming species, are already known to be widespread throughout the New Zealand region (Cairns 1995). However, recent sampling efforts have provided an opportunity to update distribution records and provide a better understanding of the association of corals with particular seafloor features and environmental conditions.

Given the general paucity of data describing the distribution of species, particularly in deeper waters, predictive models are increasingly being built using environmental factors such as depth, temperature or salinity, that are chosen for their likely roles in driving distributional patterns in the ocean (e.g. Leathwick et al. 2006). However, the ability of such models to act as good predictors of biological patterns is strongly dependent on how they are constructed, e.g. modelling technique and the environmental data used (Araújo \& Guisan 2006, Guisan et al. 2006). The global models of Tittensor et al. $(2009,2010)$ showed that the New Zealand region is particularly suitable for stony corals. However, Tittensor et al. (2009) stressed the need for ground-truthing to be conducted whenever possible, in order to properly assess modelled predictions and noted that higher-resolution environmental data or additional coral samples would allow for further refinement of models at more local scales.

Our research has been developed to provide information for the effective environmental management of the most common habitat-forming scleractinian coral species in the New Zealand region. The aim of this study was to compile the latest data, map and describe the distribution of the study species, and characterise the extent of their association with seamounts, where their habitat suitability is predicted to be high (Tittensor et al. 2009), and other geomorphic features. While our data set is extensive, there are large areas of the New Zealand region that have not been sampled. Therefore, we also aimed to predict the distribution of the study species over the entire region by modelling the relationship between the known occurrence of the corals and various environmental variables. The results of the study are intended to provide insight into factors that influence the distribution of the study species, as well as an understanding of the relative extent to which the species provide habitat for other invertebrates in the New Zealand region.

\section{MATERIALS AND METHODS}

Study area. The study region comprises the area of the General Bathymetric Chart of the Oceans (GEBCO) sheet G.09 'SW Pacific around New Zealand' bounded by the limits of $24^{\circ}$ to $57^{\circ} 30^{\prime} \mathrm{S} ; 157^{\circ} \mathrm{E}$ to $167^{\circ} \mathrm{W}$ (Fig. 1). Within this region, our modelling analysis is constrained to the limits of the New Zealand Extended Continental Shelf (ECS), the area over which the country has jurisdiction of the seafloor and which comprises 5.8 million $\mathrm{km}^{2}$. Over 47000 seabed samples 
Fig. 1. New Zealand region, showing location of major seafloor topographic features referred to in the text. The dotted line marks the boundary of the extended continental shelf. Bathymetric contours for 250, 1000 and $2000 \mathrm{~m}$ are also shown (grey lines)

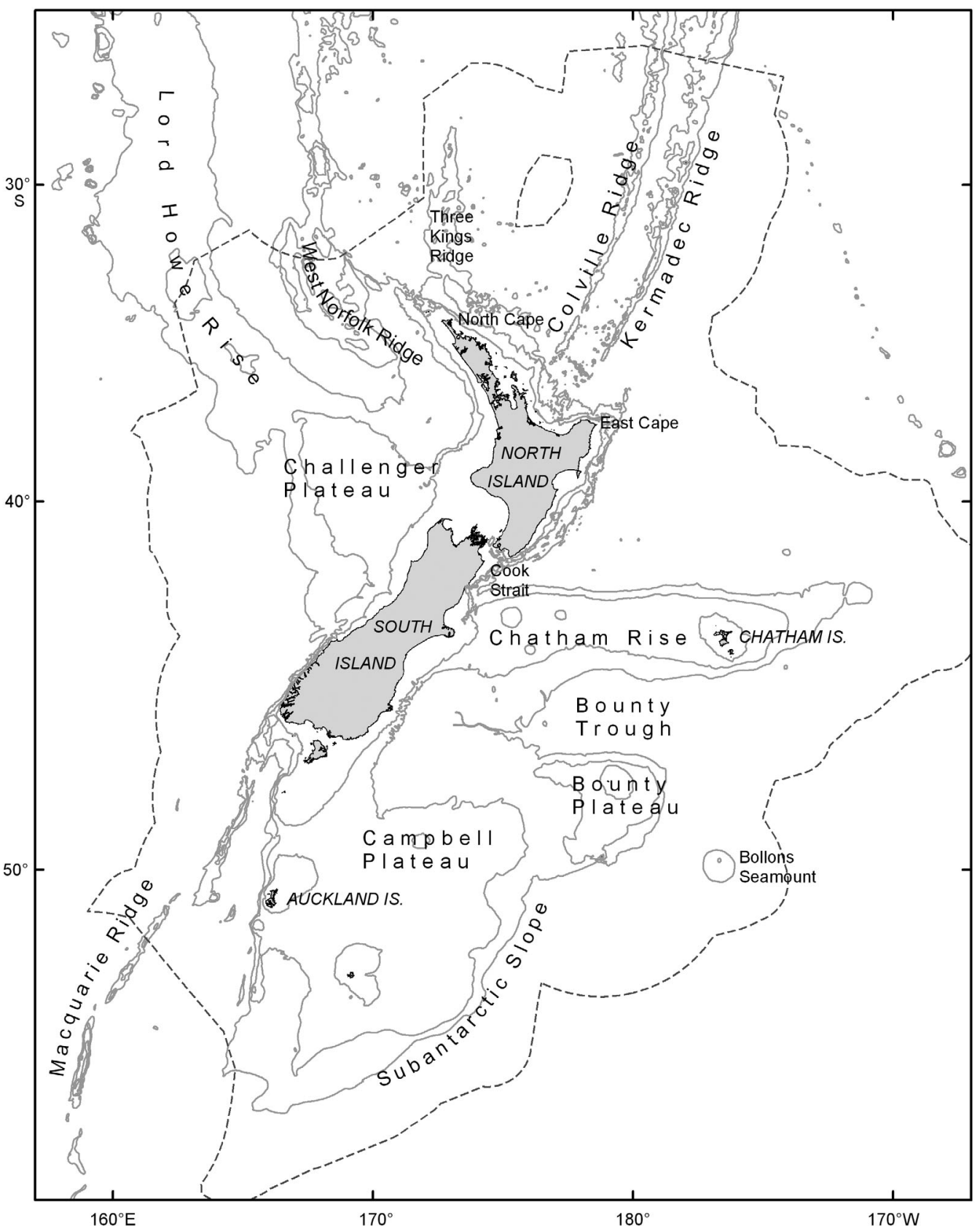

have been taken from this area to depths of greater than $6000 \mathrm{~m}$ (Fig. 2), providing an almost unprecedented opportunity to describe the biodiversity of a region, including its deep sea (Nelson \& Gordon 1997).

Study species. The dominant habitat-forming coldwater Scleractinia in the New Zealand region are Madrepora oculata, Solenosmilia variabilis, Goniocorella dumosa, Enallopsammia rostrata and the endemic species Oculina virgosa (Cairns 1995, Tracey et al. 2007). These genera have been observed to form habitat in the region at seamount features, slope margins and on flat tops of slopes or rises (Squires 1965, Dawson 1984,
Clark \& O'Driscoll 2003). Globally, these 5 genera, along with Lophelia, are the most significant habitatforming cold-water corals (Roberts et al. 2009), with 3 of these species, M. oculata, S. variabilis, and E. rostrata, being widely distributed (Freiwald et al. 2004).

Two forms of Madrepora species have been referred to in New Zealand waters, one named forma vitiae, described as a new species by Squires \& Keyes (1967), and a 'symbiotic' form, so named because of its association with commensal polychaetes (Cairns 1995). Here we treat all records as the single species $M$. oculata. Solenosmilia variabilis and Goniocorella dumosa re- 


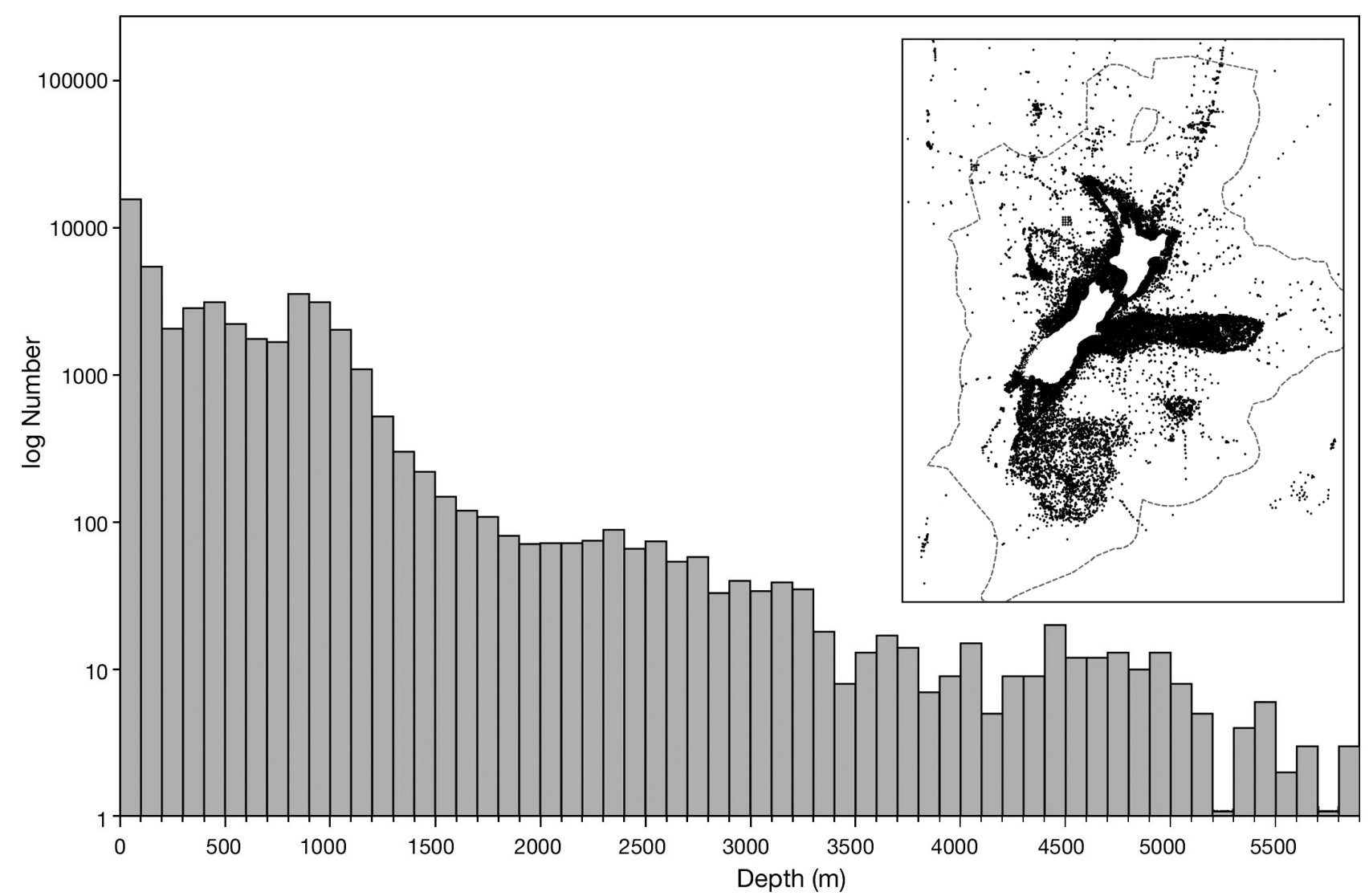

Fig. 2. Number (log) of sample stations by depth ( 47000 stations sampled between 0 and $>5500 \mathrm{~m})$ in the New Zealand region from which the records for the 5 study stony corals were taken. The inset shows sample station positions and highlights unsampled areas in the region

semble the well known habitat-forming scleractinian coral genus Lophelia. L. pertusa (Zibrowius 1980, Cairns 1984) is widely distributed in the Atlantic and has limited occurrence in the Northeast Pacific (Morgan et al. 2005), but the genus Lophelia is not found in New Zealand waters. Cairns (1982) stated that a small branch fragment of $L$. prolifera, containing only 5 damaged corallites, was sampled on the Macquarie Ridge to the south of New Zealand $\left(51^{\circ} \mathrm{S}, 162^{\circ} 01^{\prime} \mathrm{E}\right.$, 333 to $371 \mathrm{~m}$ ), during the 'Eltanin' survey in 1965 (sample number US47525; Eltanin 1411), and this record has appeared on many global maps of Lophelia (e.g. Davies et al. 2008). However, this record is now considered erroneous because the position data for the described specimen is thought to be incorrect, and no Lophelia is otherwise known to exist in the New Zealand region.

Data sources. Data to describe the distribution of Madrepora oculata, Solenosmilia variablis, Goniocorella dumosa, Enallopsammia rostrata and Oculina virgosa in the region were compiled from published historical records, 'grey literature' reports, and unpublished fisheries research trawl and commercial by- catch records, as well as from recent biodiversity research surveys.

Historical data: Records for stony corals in the New Zealand region, collected since a programme of sampling was initiated by the New Zealand Oceanographic Institute (NZOI) in 1955, were described or reviewed by Ralph \& Squires (1962), Squires (1965), Squires \& Keyes (1967) and McKnight \& Estcour (1978). Subsequently, these records and the results of later sampling were collated and included in taxonomic treatments of the scleractinian order by Cairns (1982, 1995).

Fisheries data: Coral samples have also been collected opportunistically from incidental by-catch on commercial deep-sea trawlers and during New Zealand Ministry of Fisheries research trawl surveys. Several of these corals were kept and later identified, providing valuable information on incidence of all corals on flat slope as well as on fished seamounts.

Recent biodiversity surveys: Between 1999 and 2009, the National Institute of Water and Atmospheric Research (NIWA), New Zealand, undertook a seamount research programme which in part aimed to describe 
the biodiversity of seamount features around New Zealand (Clark et al. 1999). Benthic surveys were conducted on $\sim 40$ seamounts throughout the region (Rowden \& Clark 2004), which resulted in the collection of a substantial number of records for scleractinian corals.

Data sets. Data from the various sources were compiled from a number of databases owned or maintained by NIWA with some small databases owned by other institutes. NIWA databases were cruiseDB and AllSeaBio, which include all of the historical records, and Specify, the database of the NIWA Invertebrate Collection which contains the more recent records from biodiversity surveys and corals from by-catch that are deposited in the collection. Records in the NIWA databases were cross-referenced with published material (e.g. Cairns 1995) to ensure that all records were included. If the record was not present in the NIWA databases (e.g. records from the Auckland University Museum), then they were added to the dataset used for the analysis. Research survey data from the Ministry of Fisheries trawl database and observer data from the Ministry of Fisheries COD database also provided records. Table S1 in the Supplement at www.intres.com/articles/suppl/m430p001_supp.pdf provides all the coral data used in the present study, detailing the position, depth and source of all records of the 5 habitat-forming scleractinian corals collected in the New Zealand ECS up to 2009.

Sampling methods. A range of sampling methods and equipment has been used to sample deep-sea coral in the New Zealand region, from collections taken through the lifting of telegraph cables (see Ralph \& Squires 1962) to the use of more traditional grabs, sleds and trawls (e.g. McKnight \& Estcourt 1978). Bycatch samples of coral have come from the use of bottom trawl, long-lines, and midwater trawls used on commercial vessels and fisheries research vessels.

Distribution and habitat association of observed data. Maps of the distributional records for each of the 5 study species were prepared in order to visualise the geographic pattern of species occurrence in the region. The mean and median depth and the depth range of each species were determined from the data set.

Stony coral records were associated with the main geomorphic features or habitats of the study region using ArcMap 9.3.1 GIS software suite (www.esri. com). Association with seamount features was determined in 3 ways. Seamount basal polygons were derived directly from mapping by multibeam echo sounders or by extensive surveys by single-beam echo sounders. Where no such seafloor mapping exists, a buffer of $5 \mathrm{~km}$ radius from a reported seamount position (Rowden et al. 2008) was used to generate an appropriate polygon. The figure of $5 \mathrm{~km}$ was used as a proxy because a radius of $5.07 \mathrm{~km}$ was the median value calculated from a sample of 780 suitably mapped seamounts. Finally, a 'likely' seamount association was determined for instances where a station start position was offset from the seamount but the trawl was most likely carried out on a seamount (indicated by station log). Polygons for shelf, slope, island slope, plateaux, rises, troughs and ridge features were manually delineated from the regional bathymetry map. Coral sample locations were matched against the geomorphic feature polygons using a GIS 'point-in-polygon' query which returns the coral records that are contained within each polygon feature.

Environmental data used for predictive modelling. Data for 11 environmental variables were compiled for modelling the distribution of the study species across the New Zealand ECS (Table 1). The variables used were: depth, bottom water temperature (corrected for depth), slope, seamount, sea surface current velocity, orbital current velocity, tidal current speed, sea surface temperature gradient, surface water primary productivity, dissolved organic matter and particulate organic carbon flux. The variables were selected based on the knowledge or assumption that they directly or indirectly influence the large-scale distribution of corals across the region. The predictor variables were either developed or tuned specifically for the New Zealand region (see Table 1 for details and sources). The bathymetry layer used in this study was interpolated from various sources, e.g. multi-beam and singlebeam echo sounders, and satellite gravimetric inversion, at a $250 \mathrm{~m}^{2}$ grid-scale resolution. Although depth is not a direct driver of species distributions, it was included as a surrogate for other variables that are known to influence species distributions in the deep sea, e.g. pressure, light and oxygen (Levin et al. 2001). As temperature and depth are directly correlated, residuals were derived from a generalised linear model describing the relationship between depth and temperature, using a non-linear spline (see also Leathwick et al. 2006). These residuals provide a measure of temperature that is unconfounded by depth. Temperature is known to influence the physiology and thus the distribution of cold-water stony corals (Freiwald et al. 2004, Dodds et al. 2007). Seabed slope, a proxy for a range of potentially suitable environmental conditions for corals that occur at slope margins (Frederiksen et al. 1992, Thiem et al. 2006, Reveillaud et al. 2008), was determined from the bathymetry layer. Another habitat layer, 'seamount', was used to describe seamount occurrences around the New Zealand region; the summits and upper slopes of seamounts are known to be habitats suitable for coral growth (Genin et al. 1989). Measures of productivity were described by 4 indirect productivity variables, assuming that surface water primary productivity will influence deep-water pro- 
Table 1. Description of the 11 environmental variables used in the predictive modelling analysis and their data sources

\begin{tabular}{|c|c|c|c|}
\hline Variable & Units & Description and data source & Source \\
\hline Orbital current velocity & $\mathrm{dm} \mathrm{s}^{-1}$ & $\begin{array}{l}\text { Orbital velocity at the seabed based on a wave climatology } \\
\text { derived from a } 20 \text { yr hindcast (1979-1998) of mean } \\
\text { significant wave height for the New Zealand region }\end{array}$ & $\begin{array}{l}\text { Hadfield et al. (2002), } \\
\text { Gorman et al. (2003) }\end{array}$ \\
\hline Tidal current speed & $\mathrm{m} \mathrm{s}^{-1}$ & $\begin{array}{l}\text { Maximum depth-averaged tidal current velocity estimated } \\
\text { by interpolating outputs from the New Zealand region } \\
\text { tide model }\end{array}$ & $\begin{array}{l}\text { Walters et al. (2001), } \\
\text { Hadfield et al. (2002) }\end{array}$ \\
\hline $\begin{array}{l}\text { Sea surface } \\
\text { temperature gradient }\end{array}$ & ${ }^{\circ} \mathrm{C} \mathrm{km}^{-1}$ & $\begin{array}{l}\text { Smoothed annual mean spatial gradient estimated from } \\
96 \text { mo of remotely sensed SeaWIFS data }\end{array}$ & $\begin{array}{l}\text { Uddstrom \& Oien (1999), } \\
\text { Hadfield et al. (2002) }\end{array}$ \\
\hline Seamount & - & Seamount positions recorded in New Zealand region & Rowden et al. (2008) \\
\hline Slope & Degrees & $\begin{array}{l}\text { Sea-floor slope derived from neighbourhood analysis of } \\
\text { the bathymetry data }\end{array}$ & $\begin{array}{l}\text { Hadfield et al. (2002), } \\
\text { CANZ (2008) }\end{array}$ \\
\hline $\begin{array}{l}\text { Surface water primary } \\
\text { productivity }\end{array}$ & $\mathrm{mg} \mathrm{C} \mathrm{m}{ }^{-2} \mathrm{~d}^{-1}$ & $\begin{array}{l}\text { Vertically generalised productivity model based on net } \\
\text { primary productivity estimated as a function of remotely } \\
\text { sensed chlorophyll, irradiance and photosynthetic efficiency } \\
\text { estimated fromremotely sensed sea surface temperature }\end{array}$ & $\begin{array}{l}\text { Behrenfeld \& Falkowski } \\
\text { (1997) }\end{array}$ \\
\hline $\begin{array}{l}\text { Dissolved organic } \\
\text { matter }\end{array}$ & $a_{\mathrm{DOM}}(443) \mathrm{m}^{-1}$ & $\begin{array}{l}\text { Modified Case } 2 \text { inherent optical property algorithm applied } \\
\text { to modified Case } 2 \text { atmospheric corrected SeaWiFS ocean } \\
\text { colour remotely sensed data for the New Zealand region }\end{array}$ & Pinkerton et al. (2006) \\
\hline $\begin{array}{l}\text { Particulate organic } \\
\text { carbon flux }\end{array}$ & $\mathrm{mg} \mathrm{C}_{\text {org }} \mathrm{m}^{-2} \mathrm{~d}^{-1}$ & $\begin{array}{l}\text { Particulate organic carbon flux described as a function of } \\
\text { the production of organic carbon in surface waters, scaled } \\
\text { to depth below the sea surface }\end{array}$ & Lutz et al. (2007) \\
\hline
\end{tabular}

ductivity due to the settling of detritus to the seabed which could provide a food source for corals (Duineveld et al. 2004, 2007). These variables included: sea surface temperature gradient, which indicates the major zones of water mixing (fronts) that are often associated with increased productivity; surface water primary productivity, derived from a vertically generalised productivity model based on remotely sensed estimates of chlorophyll a ( $\mathrm{chl}$ a) concentration; dissolved organic matter, also estimated from ocean colour data with an atmospheric correction and optical property algorithm; and particulate organic carbon flux, described as a function of the production of organic carbon in surface waters or the export of organic carbon from the base of the euphotic zone scaled to depth below the sea surface. Water current regime is thought to be important, principally as a delivery mechanism for food material (Genin et al. 1989, Thiem et al. 2006). Current variables used in this analysis included sea surface current velocity (as the variable 'dynamic topography'), tidal current speed and orbital current velocity at the seabed. The mean dynamic topography variable is related to mean surface current by the geostrophic relationship, i.e. current flows along the isolines of the dynamic topography. Surface currents may be responsible for moving potential food material from one location to another, whilst bottom currents may have a more direct influence upon the availability of food for corals at the seabed. All of these data (apart from seamount and bathymetry data) represent a 'climatology', i.e. they are average values over a period that is effectively determined by when the observations were made, primarily the last couple of decades. All variables were mapped in a World Mercator projection (central meridian $100^{\circ} \mathrm{E}$, standard parallel $41^{\circ} \mathrm{S}$ ) at either a $250 \mathrm{~m}^{2}$ or a $1 \mathrm{~km}^{2}$ resolution. The variables were matched to the coral data using the intersect points tool in Hawths Tools (Beyer 2004). Maps and GIS analyses were done in ArcMap 9.2 GIS software suite (www.esri.com). 
Although aragonite concentrations in seawater are known to be important for determining the global distribution of stony corals (Guinotte et al. 2006, Tittensor et al. 2010), we did not include it in this analysis. This omission is because there are very limited aragonite saturation data currently available for the region, and what data are available suggest that the aragonite saturation state varies considerably across the region, a pattern not reflected in the current coarse resolution global models (H. Bostock pers. comm.).

Statistical analysis. A number of methods are available for modelling species distribution/habitat suitability. These include ecological niche factor analysis (ENFA) and maximum entropy approaches (MaxEnt), which have already been used to predict the occurrence of cold-water corals (e.g. Tittensor et al. 2009). However, we chose to use a boosted regression trees (BRT) analysis (De'ath 2007, Elith et al. 2008) to predict the distribution of each of the 5 coral species across the region with respect to the 11 environmental variables. BRT models, an advanced form of regression analysis, have shown a higher performance and provide a number of advantages over standard regression methods such as generalised additive models (Leathwick et al. 2006, Elith et al. 2008). Regression trees can model almost any type of predictor variable, can automatically model interactions between variables, and can deal with differing scales of measurement among predictors. Boosting improves the performance of standard regression trees by stochastically fitting the data such that the emphasis during model building is placed on explaining the unexplained variation in the dataspace at each step (Elith et al. 2008). The learning rate (lr), also known as the shrinkage parameter, determines the contribution of each tree to the growing model, and the tree complexity (tc) controls whether interactions are fitted (Elith et al. 2008). All analyses were carried out in $\mathrm{R}$ (version 2.0.1, R Development Core Team) using the 'gbm' library of Ridgeway (2006), supplemented with functions from Elith et al. (2008).

Although the coral observations in this study were derived from as many data sources as possible from within the region, these samples may reflect arbitrary sample biases and do not include true absence data points. As most predictive models need a measure of sample absence, pseudoabsences can be used instead to provide a measure of the background environment across the sampled region (Phillips et al. 2009). Here, we used location records (see Fig. 2) from research voyages that were carried out over the same period as the coral data collection, but where no corals were recorded when using the same sampling gear types, to provide pseudoabsence data (10 000 randomly selected sample points from $\sim 4000$ stations). The pseudoabsence data were restricted to the maximum depth at which a species was recorded. Be- cause these targeted pseudoabsences reflect the background environment where corals were not observed, their inclusion should enable the BRT model to focus on distributional differences between the recorded observations and the background data, and not on any sample selection biases (Phillips et al. 2009).

As the number of pseudoabsences outnumbered the number of presences in the model for each species, we down-weighted the overall influence of the pseudoabsences such that their weights were constant and scaled to equal the sum of the presence observations. The influence of the environmental variables to the explanatory power of each BRT model was assessed using functions provided by Elith et al. (2006). Model performance was assessed using cross-validated measures of deviance, discrimination and correlation. Model performance was also assessed during cross-validation (1/10 to 10 -fold cross-validation) by comparing model predictions to held portions of the data (Elith et al. 2006). The null deviance provides a measure of variation where there are no covariates, i.e. a model with a constant term of 1 , and the explained deviance gives a measure of the goodness of fit between the predicted and raw values, and is here also expressed as a percentage of the null deviance for each species (Leathwick et al. 2008). An AUC value of 0.5 indicates that presences and absences are discriminated no better than random, whereas 1.0 indicates perfect discrimination (Leathwick et al. 2008). To identify the final set of variables that optimise the model, we used a model simplification code that sequentially dropped variables that did not change the cross-validated deviance of each model (Elith et al. 2008). In all cases, only the final simplified model is presented. Note that by contrast with standard regression approaches, which aim to achieve the most parsimonious model, BRT models can handle more predictor variables because variables with a small explanatory power are downweighted such that they have a minimal effect on model performance and prediction in the final BRT model (Elith et al. 2008).

Spatial predictions of coral occurrence were produced using the predict.gbm function (Ridgeway 2006) and were displayed in ArcGIS 9.2. All predictions were constrained to the maximum depth of occurrence for each coral species (see Table S1 in the Supplement) so that we did not over-predict to areas outside of the depth range encountered by each species. We believe that sampling above and beyond the depth where the study corals have been recorded has been sufficient to determine their actual depth distribution. As the 'seamount' data layer was a categorical variable, the maximum value associated with each species was used for producing the spatial predictions. Spatial predictions were produced at a $1 \mathrm{~km}^{2}$ resolution. 

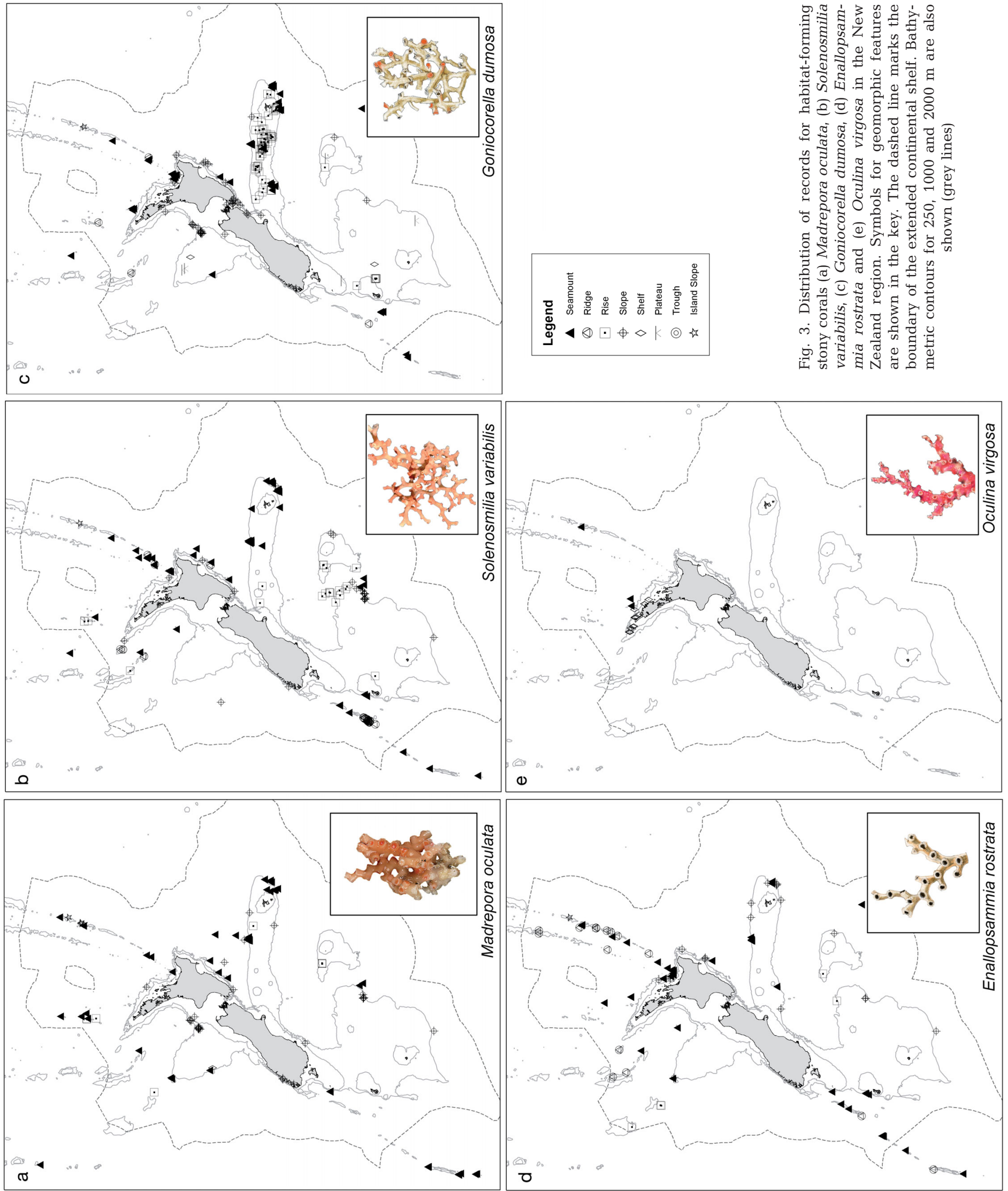
Table 2. Number and percentage of records, and depth ranges for habitatforming stony coral species in the New Zealand region

\begin{tabular}{|c|c|c|c|c|c|c|}
\hline \multirow[t]{2}{*}{ Taxon } & \multirow{2}{*}{$\begin{array}{l}\text { No. of } \\
\text { records }\end{array}$} & \multirow{2}{*}{$\begin{array}{l}\% \text { of total } \\
\text { records }\end{array}$} & \multicolumn{4}{|c|}{ Depth $(\mathrm{m})$} \\
\hline & & & Mean & Median & Min. & Max. \\
\hline Madrepora oculata & 118 & 19 & 736 & 802 & 90 & 2850 \\
\hline Solenosmilia variabilis & 191 & 30 & 976 & 976 & 265 & 1700 \\
\hline Goniocorella dumosa & 204 & 32 & 482 & 395 & 88 & 1488 \\
\hline Enallopsammia rostrata & 98 & 16 & 789 & 781 & 202 & 2147 \\
\hline Oculina virgosa & 20 & 3 & 180 & 105 & 29 & 792 \\
\hline
\end{tabular}

\section{Depth, distribution and habitat association of observed data}

Four of the study species had a broad depth and geographic distribution (Fig. 3, Table 2). Oculina virgosa was the exception, being found in shallow shelf regions from 29 to $\sim 250 \mathrm{~m}$ in the subtropical waters off the extreme northern part of New Zealand. However, a small number of deeper records for $O$. virgosa occurred on seamounts at 670 to $880 \mathrm{~m}$ depth (Fig. 3e, Tables 2 \& 3). The remaining

For comparison, we produced presence-only MaxEnt models (Phillips et al. 2006) for each species in order to qualitatively evaluate the robustness of the output from our BRT analysis using pseudoabsences.

\section{RESULTS}

\section{Study dataset}

Data for each of the 5 study species are presented in Table S1 in the Supplement. By 1962, only 2 of the species had been recorded for the New Zealand region, but by 2009, a total of 631 records existed from 552 sampling stations for the 5 coral species. Most records (95\%) are from depths greater than $200 \mathrm{~m}$ and extend to a maximum depth of $2850 \mathrm{~m}$. Only 2 records are from depths greater than $2000 \mathrm{~m}$. Of the 552 stations where the study stony corals were present, 478 (87\%) had only 1 species present, $69(12 \%)$ had at least 2 species present, and 5 stations $(1 \%)$ had 3 of the species present. In the study region, the most southern, northern, western and eastern records were from $26.7^{\circ}$ to $56.3^{\circ} \mathrm{S}$ and $158.4^{\circ} \mathrm{E}$ to $174.4^{\circ} \mathrm{W}$, respectively. Fig. 2 illustrates the depth and geographic distribution of the $\sim 4000$ sample stations between 0 and $>5500 \mathrm{~m}$ from which the 631 coral records are drawn. This figure illustrates the spatial envelope in which it is reasonable to interpret the coral distribution records. habitat-forming species were distributed throughout the region in deeper waters, ranging mainly from $\sim 200 \mathrm{~m}$ to a maximum depth of $2850 \mathrm{~m}$ (Table 2). Madrepora oculata was found between 90 and $2850 \mathrm{~m}$, predominantly on seamounts (65\% of records) and slopes (24\%) (Tables $2 \& 3$ ). There was a northern region bias to the distribution of M. oculata (Fig. 3a). Solensmilia variablis was found at depths from 265 to $1700 \mathrm{~m}$, with the highest proportion of records (62\%) from seamounts (Tables 2 \& $3)$. This species was distributed throughout the entire region, occurring relatively frequently on rises, ridges and slopes, as well as seamounts (Fig. 3b). Gonicorella dumosa was found over a wide range of depths, between 88 and $1488 \mathrm{~m}$ throughout the region (Table 2, Fig. 3c), and was recorded reasonably equally from rises $(34 \%)$, seamounts $(36 \%)$ and slopes $(24 \%)$ (Table 3$)$. This species was particularly common on the Chatham Rise (Fig. 3c). Enallopsammia rostrata occurred between 202 and $2147 \mathrm{~m}$ depth throughout the region, with $56 \%$ of records coming from seamounts, $21 \%$ from slopes and $15 \%$ from ridges (Tables $2 \& 3$ ). This species was particularly associated with the Kermadec and Macquarie Ridge features (Fig. 3d).

\section{Predictive models}

The BRT models describing the occurrences of the 5 coral species had high predictive performances, as assessed using cross-validation (AUC >0.85, Table 4).

Table 3. Number and percentage (in parentheses) of habitat-forming stony coral species by geomorphic seafloor feature in the New Zealand region. The highest habitat association (percentage of records for a particular geomorphic feature) is indicated in bold

\begin{tabular}{|c|c|c|c|c|c|c|c|c|}
\hline Taxon & Trough & Slope & Rise & Ridge & Island slope & Seamount & Plateau & Shelf \\
\hline Madrepora oculata & - & $28(23.7)$ & $8(6.8)$ & $0(0)$ & $4(3.4)$ & $77(65.3)$ & - & $1(0.8)$ \\
\hline Solensmilia variabilis & - & 26 (13.6) & $21(11.0)$ & $24(12.6)$ & $1(0.5)$ & $119(\mathbf{6 2 . 3})$ & - & - \\
\hline Goniocorella dumosa & - & $49(24.0)$ & $70(34.3)$ & $4(2.0)$ & $1(0.5)$ & $72(\mathbf{3 5 . 3})$ & $6(2.9)$ & $2(1.0)$ \\
\hline Enallopsammia rostrata & $1(1.4)$ & $21(21.4)$ & $5(5.1)$ & 15 (15.3) & $1(1.0)$ & $55(\mathbf{5 6 . 1})$ & - & - \\
\hline Oculina virgosa & - & - & - & - & - & $3(15)$ & - & $17(\mathbf{8 5})$ \\
\hline
\end{tabular}


Table 4. Predictive performance estimates of the boosted regression trees (BRT) models for habitat-forming stony coral species in the New Zealand region. The number of records used in the model and the maximum depth of each species are shown. The models explained deviance and standard error (SE), percentage (\%) predicted deviance, and area under the curve (AUC). lr: learning rate, ntree: number of trees. Where applicable, values are $\pm \mathrm{SE}$

\begin{tabular}{|lcccccccc|}
\hline Species/model & $\begin{array}{c}\text { No. of records } \\
\text { used in model }\end{array}$ & $\begin{array}{c}\text { Maximum } \\
\text { depth (m) }\end{array}$ & $\begin{array}{c}\text { Null } \\
\text { deviance }\end{array}$ & $\begin{array}{c}\text { Explained } \\
\text { deviance }\end{array}$ & $\begin{array}{c}\text { Predicted } \\
\text { deviance (\%) }\end{array}$ & AUC & lr & ntree \\
\hline Madrepora oculata & 106 & 2850 & 0.0279 & $0.014 \pm 0.002$ & 48 & $0.93 \pm 0.016$ & 0.00125 & 2000 \\
Solenosmilia variablis & 180 & 1920 & 0.0479 & $0.030 \pm 0.001$ & 64 & $0.97 \pm 0.006$ & 0.0025 & 1100 \\
Goniocorella dumosa & 199 & 1556 & 0.0534 & $0.018 \pm 0.002$ & 34 & $0.87 \pm 0.012$ & 0.0025 & 1050 \\
Enallopsammia rostrata & 94 & 2147 & 0.0249 & $0.012 \pm 0.001$ & 52 & $0.94 \pm 0.010$ & 0.00125 & 1650 \\
Oculina virgosa & 19 & 880 & 0.0064 & $0.003 \pm 0.001$ & 39 & $0.92 \pm 0.042$ & 0.000625 & 1450 \\
\hline
\end{tabular}

Table 5. Average percentage contributions of the environmental predictors of the boosted regression tree (BRT) models for the habitat-forming stony coral species. The 2 variables with the highest average contribution are highlighted in bold

\begin{tabular}{|c|c|c|c|c|c|}
\hline Variable & $\begin{array}{c}\text { Madrepora } \\
\text { oculata }\end{array}$ & $\begin{array}{c}\text { Solenosmilia } \\
\text { variablis }\end{array}$ & $\begin{array}{l}\text { Goniocorella } \\
\text { dumosa }\end{array}$ & $\begin{array}{c}\text { Enallopsammia } \\
\text { rostrata }\end{array}$ & $\begin{array}{l}\text { Oculina } \\
\text { virgosa }\end{array}$ \\
\hline Seamount & 34 & 13 & 15 & 12 & 3 \\
\hline Sea surface temperature gradient & 9 & 5 & 3 & 5 & 0 \\
\hline Orbital current velocity & - & - & 9 & 0 & 1 \\
\hline Surface water primary productivity & 3 & 5 & 3 & 13 & 7 \\
\hline Tidal current speed & 3 & 0.5 & 9 & 2 & 5 \\
\hline Dissolved organic matter & 22 & 6 & 2 & 18 & 7 \\
\hline Bottom water temperature (residuals) & 7 & 2 & 3 & 1 & 43 \\
\hline Depth & 6 & 61 & 45 & 18 & 1 \\
\hline Slope & 5 & 1 & 8 & 13 & 25 \\
\hline Particulate organic carbon flux & 4 & 6 & 3 & 20 & 9 \\
\hline Sea surface current velocity (dynamic topography) & 8 & 1 & - & - & - \\
\hline
\end{tabular}

Performance measures were highest for Madrepora oculata, Solenosmilia variabilis, Enallopsammia rostrata and Oculina virgosa (AUC >0.92), and lowest for Goniocorella dumosa (AUC 0.87). Although the relative contribution of the 11 environmental variables differed greatly between species, the BRT models generally predicted that 3 of the 5 species occur in deep waters (>1000 m), whereas G. dumosa and O. virgosa would be found in relatively shallower waters. The models also predicted that 4 of the 5 species would have occurrences that were associated with the presence of seamounts, the exception being $O$. virgosa (Table 5, Fig. 4e).

The widely distributed coral Madrepora oculata was identified by the BRT model to be strongly associated with seamount presence (34\%) and high dissolved organic matter $(22 \%)$. Other variables of lesser importance in explaining the occurrence of this species were sea surface temperature gradient, bottom temperature residuals and dynamic topography $(9,7$ and $8 \%$, respectively). Occurrences of $M$. oculata were predicted to be highest in areas of low productivity, i.e. at low values of surface primary productivity, dissolved organic matter, sea surface temperature gradient and particulate organic carbon flux (Fig. 4a). Consistent with the wide distribution of this species, the fitted function for depth showed that this species could be predicted to occur between 200 and $2750 \mathrm{~m}$ depth, with peaks in occurrence at $\sim 1500$ and $2750 \mathrm{~m}$. Steep seabed slopes and tidal current speeds of 0 to $0.4 \mathrm{~m} \mathrm{~s}^{-1}$ were also positively associated with the occurrence of M. oculata. This species was also more strongly associated with relatively high dynamic topography, and with both warm water masses (temperature residuals $>0$ ) and cold water masses (temperature residuals <0). Spatial predictions identified that this species was broadly distributed but scattered around the region in concordance with this coral's strong association with seamount presence. However, the spatial predictions did not identify recorded observations along the southeast coast of the North Island and Fiordland.

The BRT model for Solenosmilia variabilis had the highest predictive performance (AUC 0.97). The variables identified as being most important for describing its distribution were depth and seamount presence (61 and 13\%, respectively, Table 5). Other variables of lesser importance included orbital current velocity $(5 \%)$ and the productivity measures of surface water primary productivity, dissolved organic matter and particulate organic carbon flux $(5,6$ and $6 \%$, respectively). Probabilities of occurrence of $S$. variabilis were 


\section{Madrepora oculata}

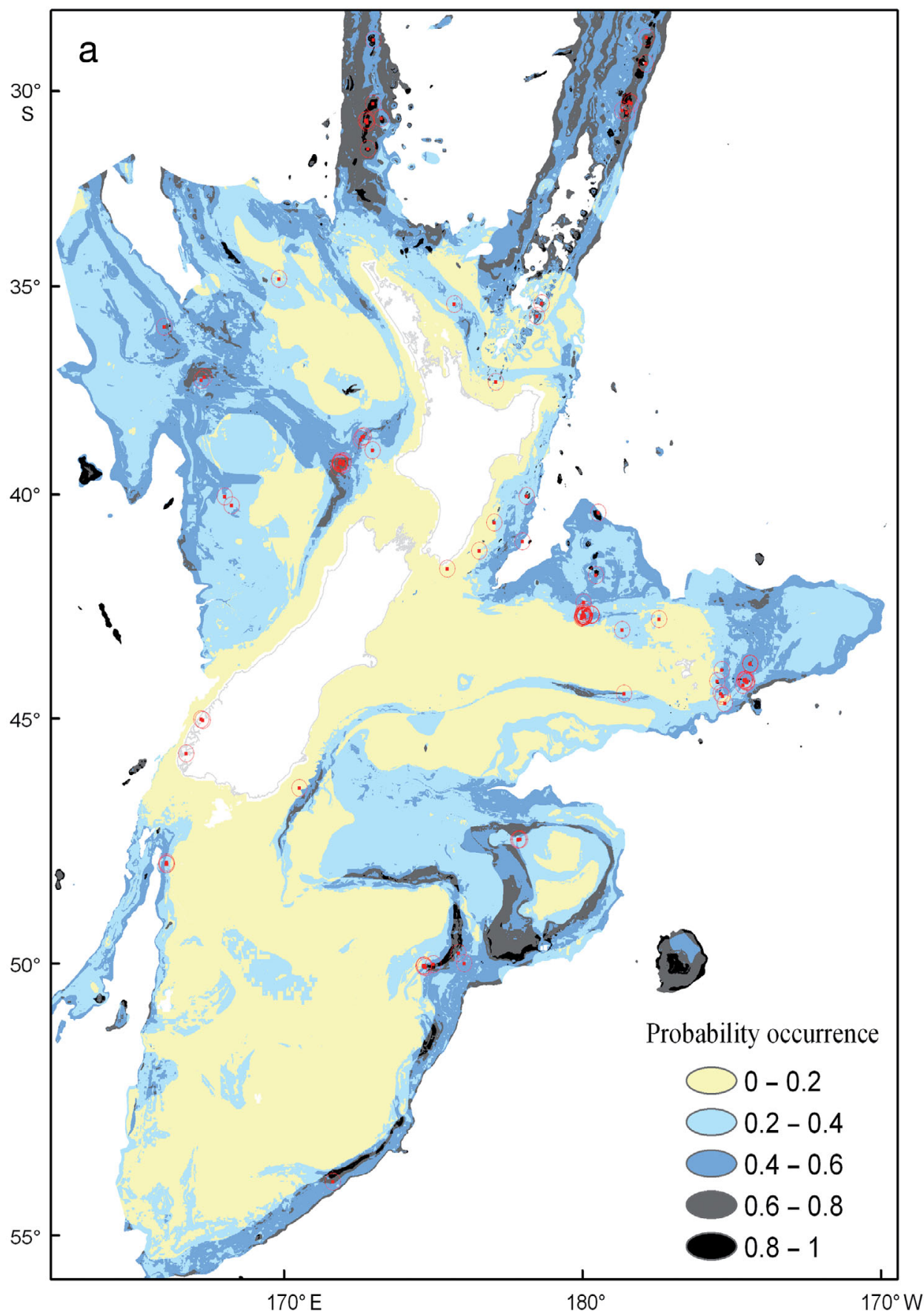

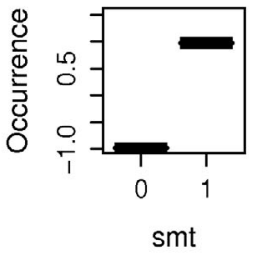
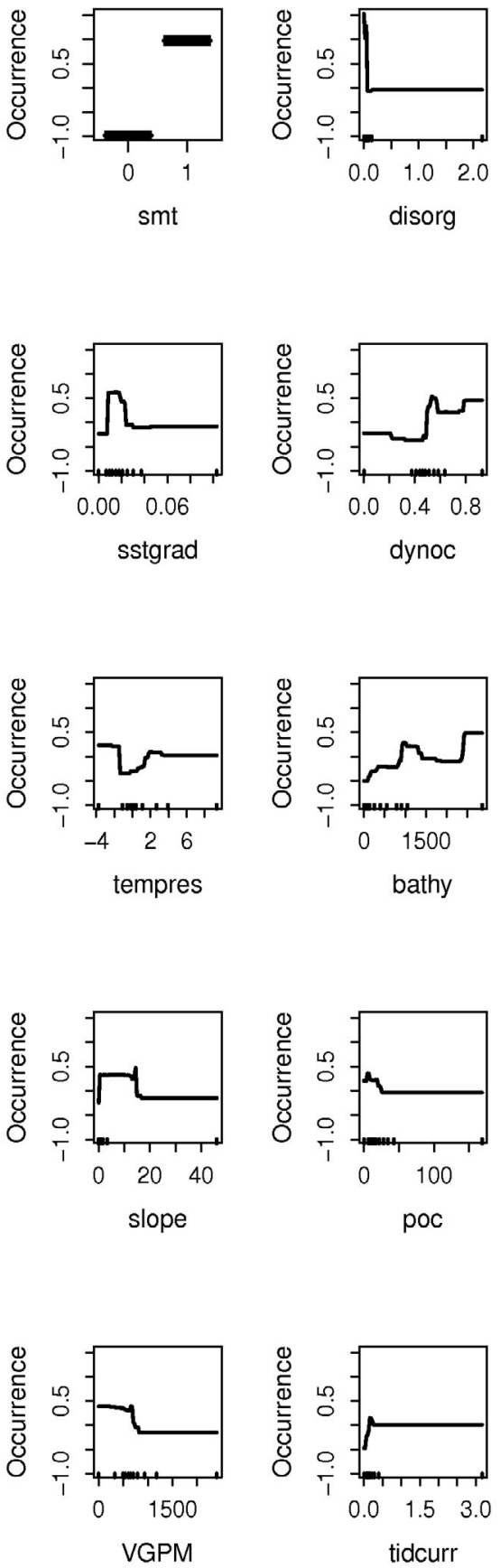

Fig. 4. (this and the next 4 pages.) Observed and predicted distributions for the habitat-forming stony coral species (a) Madrepora oculata, (b) Solenosmilia variablis, (c) Goniocorella dumosa, (d) Enallopsammia rostrata and (e) Oculina virgosa. Observed data are shown as red dots in red circles. Predicted probability of occurrence from boosted regression tree (BRT) models is shown as categories detailed in the legend up to the maximum recorded depth for the species. The fitted functions of the boosted regression tree model are shown to the right of the figure for selected variables, where $y$-axes are on the logit scale and are centred to have 0 mean over the data distribution. Variable abbreviations are: orbvel = orbital current velocity; tidcurr $=$ tidal current speed; dynoc $=$ dynamic topography; sstgrad $=$ sea surface temperature gradient; smt $=$ seamount; tempres $=$ bottom water temperature (temperature residuals); bathy $=$ depth; slope $=$ slope; VGPM = surface water primary productivity; disorg $=$ dissolved organic matter; poc $=$ particulate organic carbon flux. Rug plots show distribution of sites across that variable, in deciles. Straight lines indicate there are no data to describe the shape of the fitted function 


\section{Solenosmilia variablis}
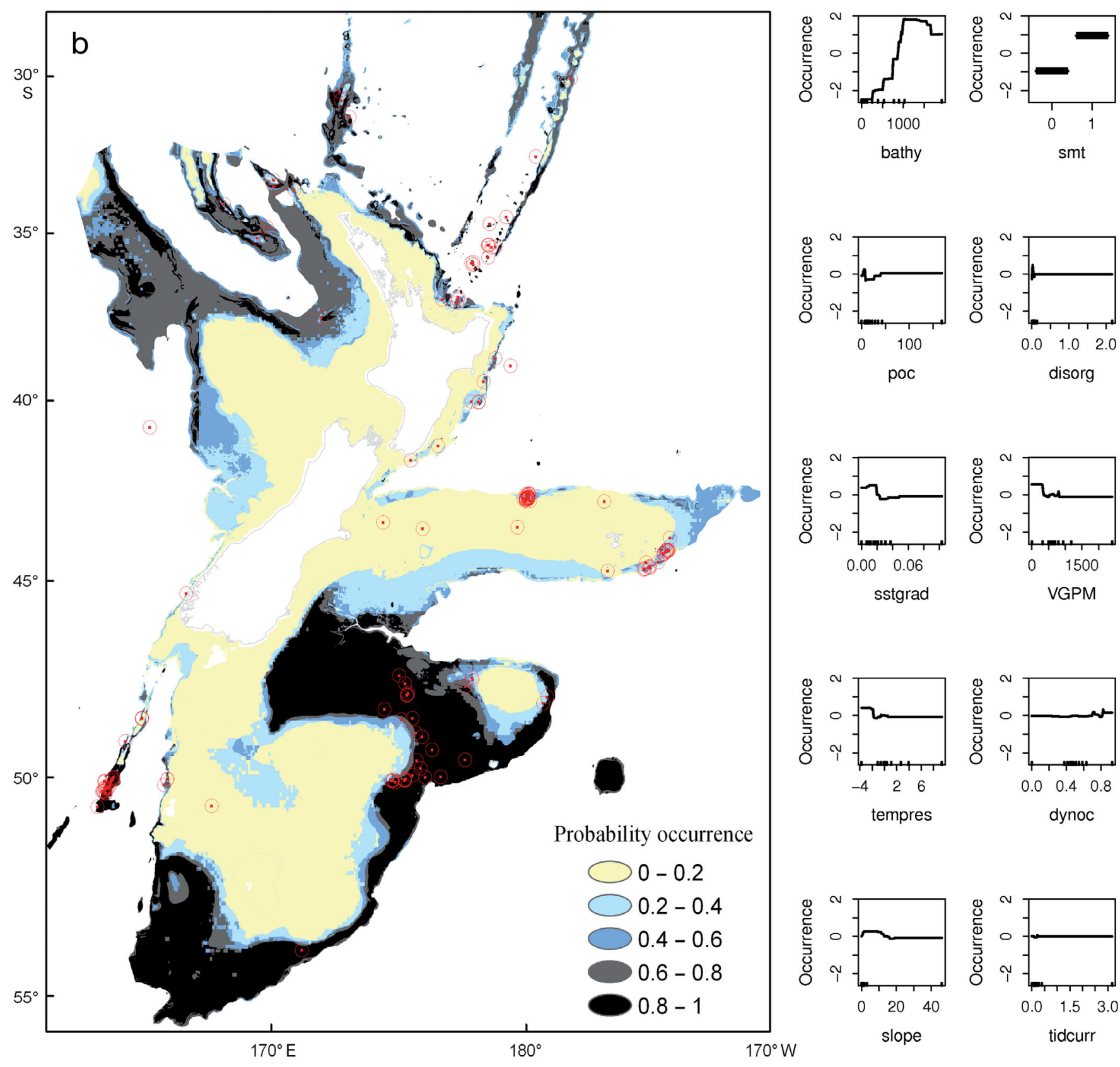

Fig. 4 (continued)
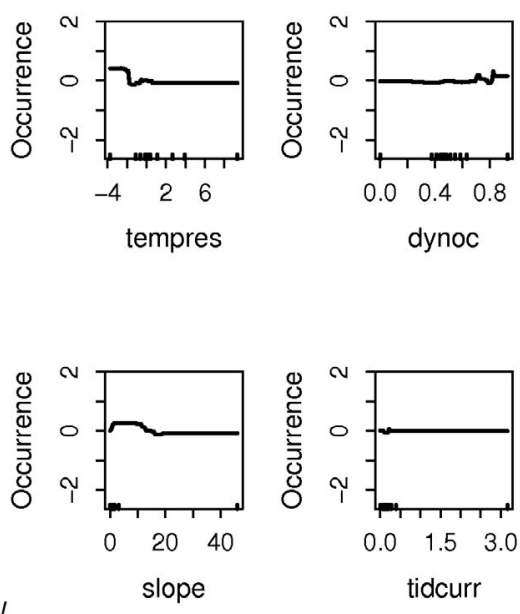

predicted to be highest at depths greater than $1000 \mathrm{~m}$. In addition, probabilities of occurrence were associated with low productivity, i.e. highest occurrences were predicted at low levels of particulate organic carbon flux, dissolved organic matter, sea surface temperature gradient and surface water primary productivity. $S$. variabilis was also predicted to have a broad geographic distribution, occurring in areas with both cool (temperature residuals <2) and warm water masses (dynamic topography >0.6, Fig. 4b). Spatial predictions identified most currently recorded observations of $S$. variabilis. However, areas where the recorded observations were not predicted by the model included an isolated record on the Challenger Plateau, and records along the east coast of the north island and some records on the Chatham Rise.

The occurrence of 1 of the 2 shallow occurring species, Goniocorella dumosa, was best predicted by depth and seamount (45 and 15\%, respectively, Table 5). Other variables describing the habitat that played a less important role included orbital current velocity, tidal current speed and slope $(9,9$ and $8 \%$, respectively). The fitted 


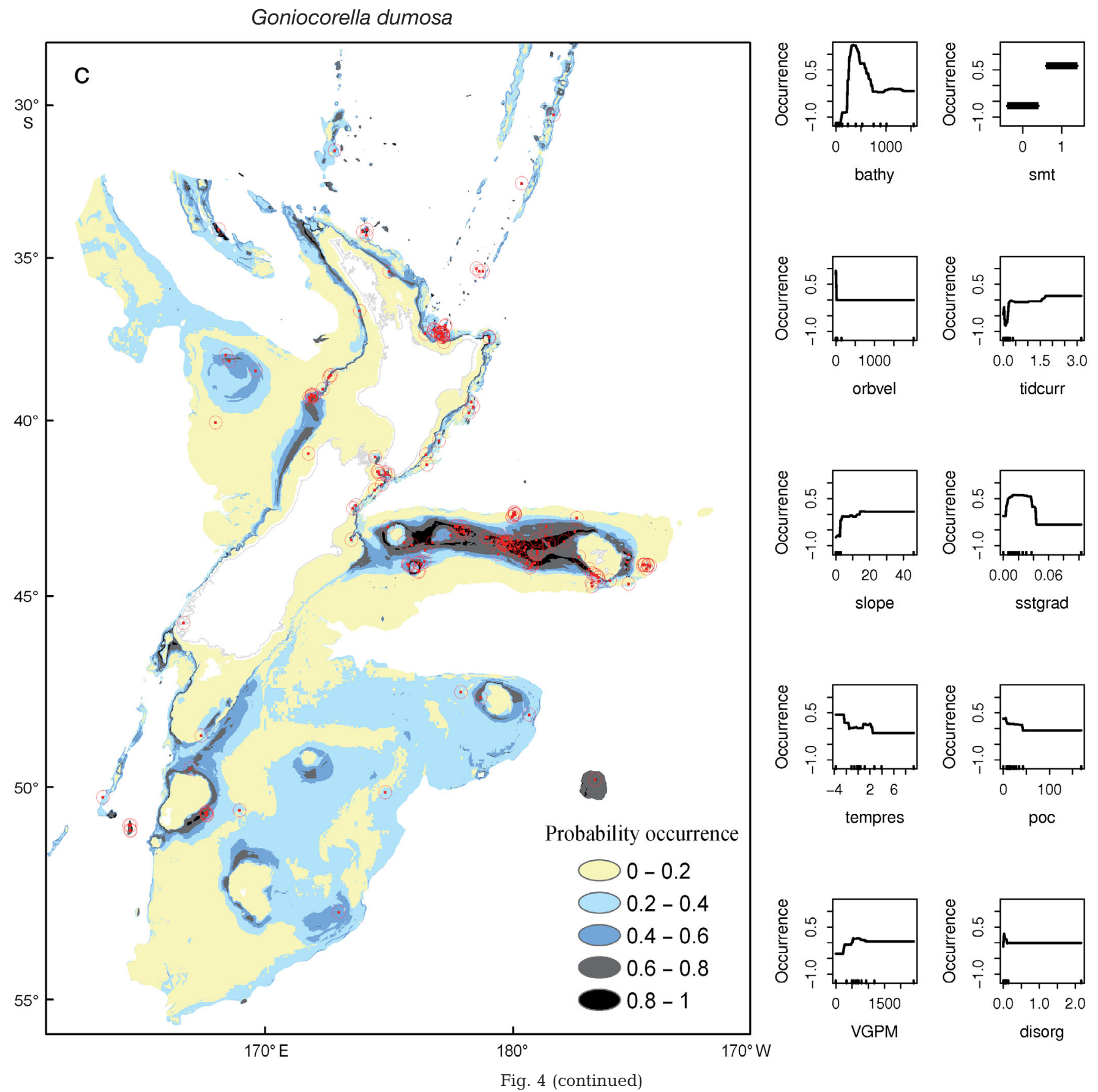

functions describing the association between G. dumosa occurrences and the environmental variables identified that this species was most commonly associated with a depth of $\sim 500 \mathrm{~m}$, steep seabed slopes (5 to $20^{\circ}$ ) and seamounts (Fig. 4c). This species was also associated with slow seabed orbital velocity but fast tidal current speeds. Although this species was associated with high values of surface water productivity, it was also associated with low levels of particulate organic carbon flux and dissolved organic matter, indicating lower productivity. This species was also predicted to occur in cooler waters ( $<1$ temperature residual). Spatial predictions of G. dumosa identified most current observances of this species, especially across the Chatham Rise.

In the case of Enallopsammia rostrata, depth, particulate organic carbon flux and dissolved organic matter were identified by the BRT model as most important for describing the occurrences of this species $(18,20$ and $18 \%$, respectively, see Table 5). Other variables that played a role but were of lesser importance included slope $(13 \%)$, surface water primary productivity $(13 \%)$ and seamount $(12 \%)$. The fitted functions 


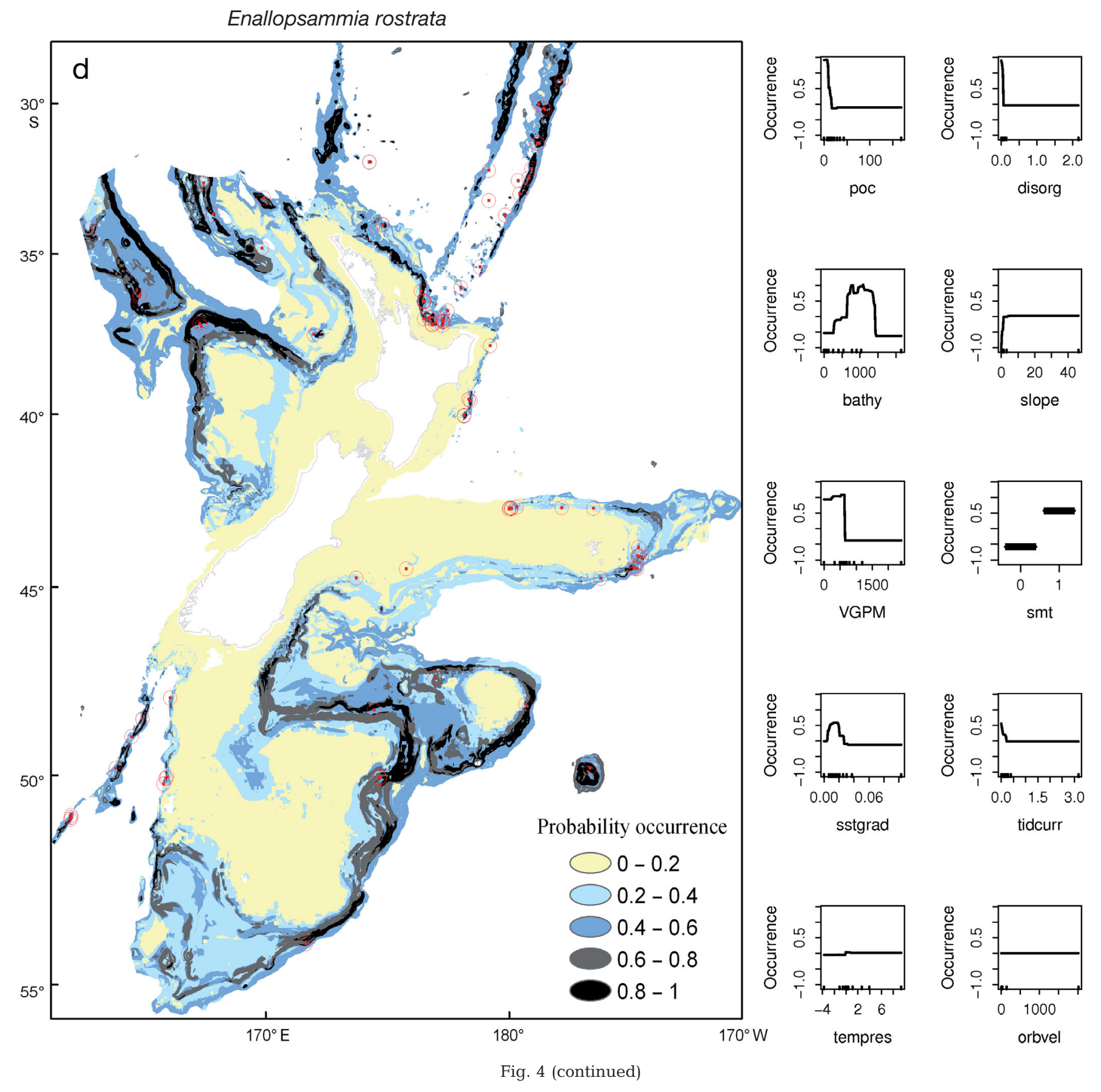

describing the occurrence of E. rostrata showed that this species occurs mainly in low-productivity areas, i.e. low particulate organic carbon flux, low dissolved organic matter, low sea surface temperature gradient and low surface water primary productivity, and in deep areas (500 to $1500 \mathrm{~m}$ ) with steep slopes (slope $\left.>5^{\circ}\right)$ where tidal currents are slow $\left(<0.2 \mathrm{~m} \mathrm{~s}^{-1}\right)$. In addition, this species was identified as being associated with known seamounts in the New Zealand region. Spatial predictions correctly identified most of the recorded observations of E. rostrata that occur in deep waters around New Zealand (Fig. 4d). However, some areas where recorded observations were not predicted included the northeastern and the southwestern slope of the Chatham Rise.

Although there were only a few recorded observations of Oculina virgosa occurrence, the BRT model described the distribution of this species with a high level of accuracy (AUC 0.92). The most important variables identified as describing the occurrence of $O$. virgosa included depth-corrected temperature (34\%) and seabed slope (25\%, Table 5). Other variables that 


\section{Oculina virgosa}

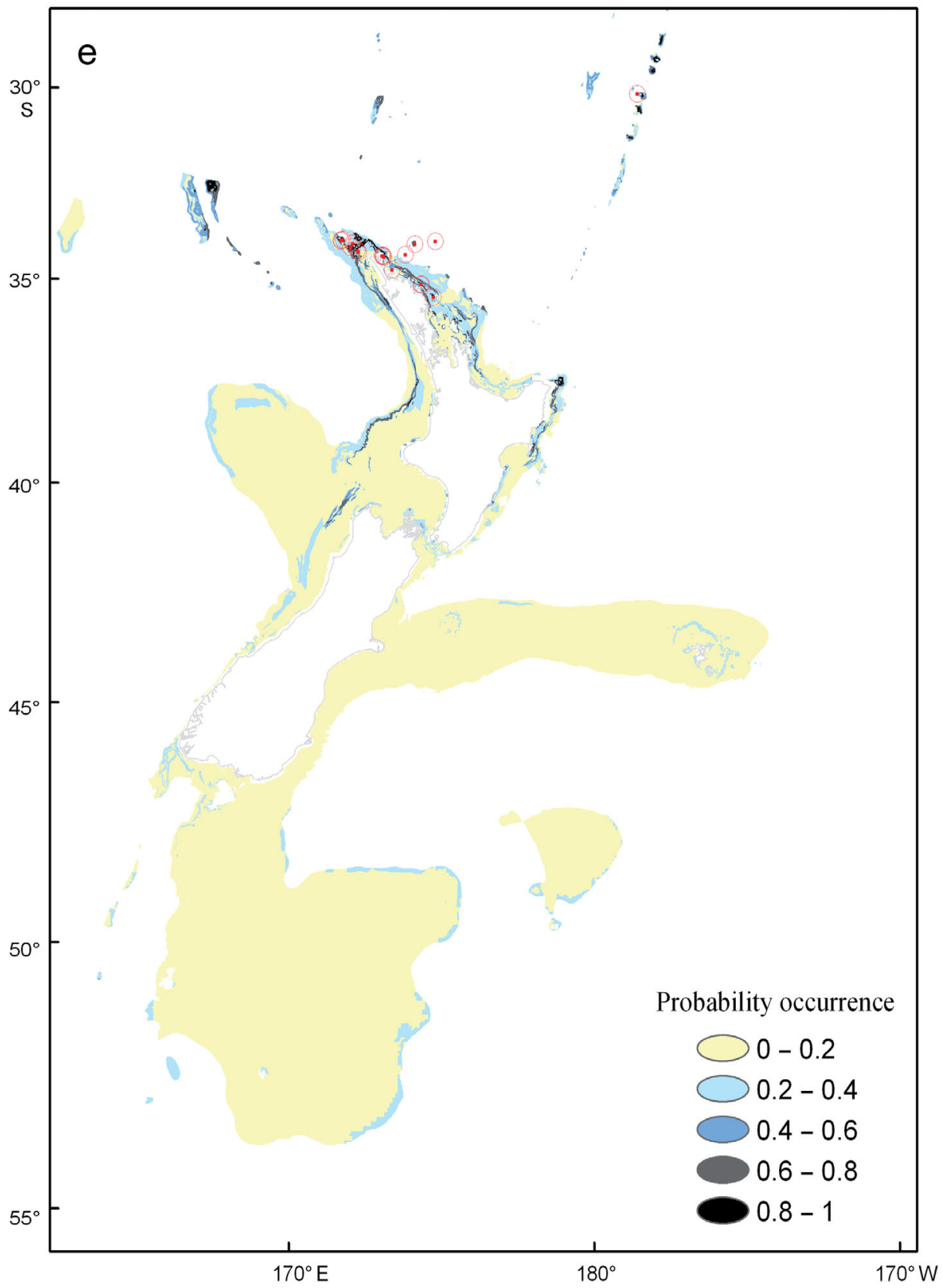

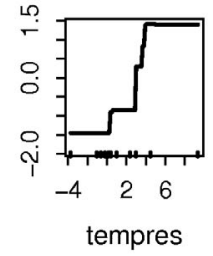
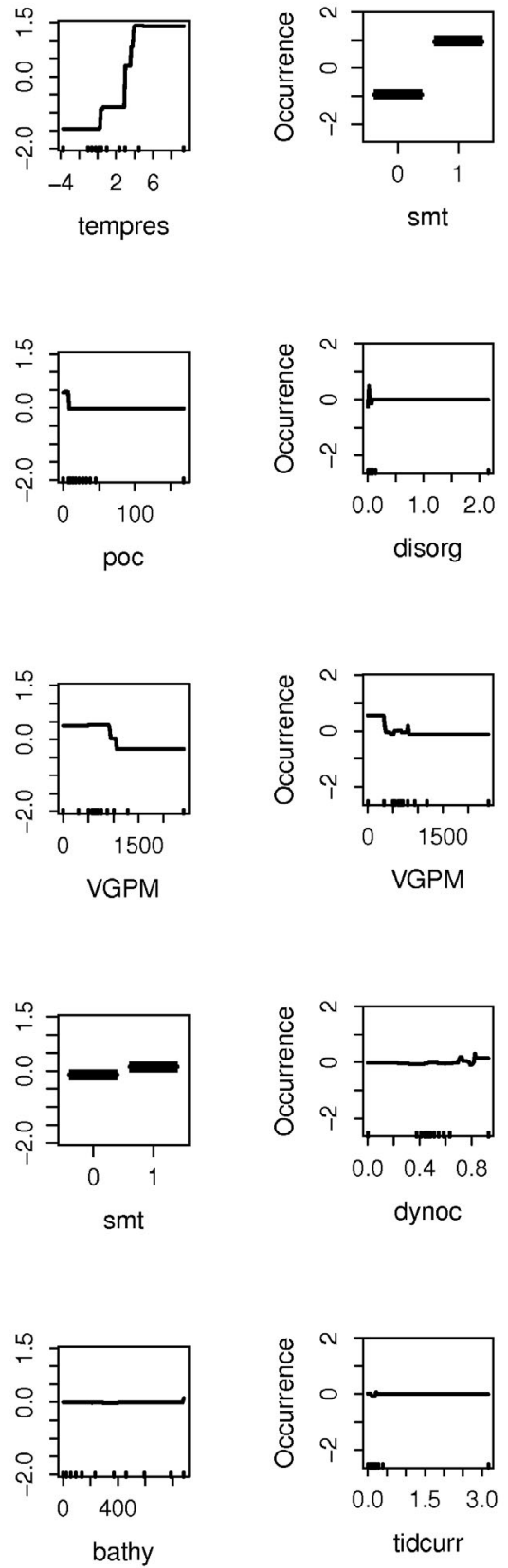

Fig. 4 (continued)

played a less important role in describing $O$. virgosa occurrence included variables associated with primary productivity: surface water primary productivity, dissolved organic matter and particulate organic carbon flux $(7,7$ and $9 \%$, respectively). The fitted functions identified that $O$. virgosa occurrences were associated with warmer waters (temperature residuals $>2$ ) where surface water primary productivity was low to moderate ( 0 to $1400 \mathrm{mg} \mathrm{C} \mathrm{m}^{-2} \mathrm{~d}^{-1}$; Fig. $4 \mathrm{e}$ ), and where particulate organic carbon flux and dissolved organic matter levels were low. The fitted functions also identified that $O$. virgosa occurrences were more often associated with seamount structures than not, and occurred in areas of high tidal currents. The variables orbital velocity, depth and sea surface temperature gradient played a minor role in explaining $O$. virgosa occurrence. Spatial predictions of $O$. virgosa occurrence coincided with recorded observations of $O$. virgosa.

Compared to the results of the BRT analysis, the presence-only MaxEnt models produced qualitatively similar predictions of species distribution across the study region (results not shown). 


\section{DISCUSSION}

Our compilation of records for 5 stony corals species complements recent efforts to utilise data from many sources, gathered over decades, to better understand and map the distribution of corals in the New Zealand region, including those that are protected (under the revised 1953 Wildlife Act, www.legislation.govt.nz/ act/public/1953/0031/latest/DLM278598.html), and/or are of particular ecological importance (e.g. Smith et al. 2004, Sanchez 2005, Consalvey et al. 2006). Our modelling focus also follows the recent trend in making use of relatively sparse biological data to predict the distribution of cold-water corals on regional and global scales (Bryan \& Metaxas 2006, 2007, Davies et al. 2008, Tittensor et al. 2009). As with the present study, much of this type of research has been partly aimed at providing information that will aid in the development of management strategies that could provide protection and conservation of these vulnerable and at-risk taxa (Clark \& Tittensor 2010).

\section{Observed distribution and habitat association}

The deep-sea corals of New Zealand received little attention until a summary of their distribution and a literature review was prepared by Ralph \& Squires (1962). Early sampling was centred on a few areas, with only scattered records from other parts of the region. Squires (1965) reported the first known significant deep-sea coral structure, describing a 'coppice' comprised primarily of Goniocorella dumosa located southeast of the Auckland Islands, as well as 2 additional structures on the Chatham Rise. Squires \& Keyes (1967) reviewed scleractinian coral data obtained by NZOI, which though obviously influenced by sampling distribution, showed coral distribution, including that of the habitat-forming stony corals, to extend around the New Zealand shelf and along the north and south Chatham Rise. From the 1970s, many more coral records were added to the existing data, including records for the 'branching coral Madrepora vitiae' in Caswell Sound, in the Fiordland region of New Zealand (McKnight \& Estcourt 1978). Cairns (1982) provided coral records from the sub-Antarctic part of the New Zealand region. A thorough revision of the scleractinian fauna of New Zealand was undertaken by Cairns (1995), which included a large number of previously unexamined samples and extended the known geographic distribution of the region's stony corals. Some records from NIWA's seamount programme were combined with these historical data by Burgess (2002) to describe the distribution of 5 stony coral species (including 4 of the present study species and the cup coral Desmophyllum dianthus). Burgess (2002) found that the stony corals showed some regional variation and a non-uniform depth distribution pattern.

The results of compiling both the historical records of habitat-forming stony corals and the more recently sampled records (those from commercial and research trawls as bycatch and seamount programme samples, and international surveys, such as the German RV 'Sonne', Hoernle et al. 2003) for the present study show that Madrepora oculata, Enallopsammia rostrata and Solenosmilia variablis are all widely distributed in the New Zealand region. These species are most commonly found at water depths of $\sim 800$ to $1000 \mathrm{~m}$, with $S$. variabilis having a maximum depth record of $1700 \mathrm{~m}$ and $M$. oculata and E. rostrata occurring down to depths $>2000 \mathrm{~m}$. Goniocorella dumosa also occurs throughout the region but is generally found at shallower depths $(\sim 400 \mathrm{~m})$, although it has a maximum recorded depth of $\sim 1500 \mathrm{~m}$. The final study species, Oculina virgosa, most often occurs in relatively shallow water $(\sim 100 \mathrm{~m})$ in the northern part of the region. Previously recorded depth ranges for the most cosmopolitan of the study species, $M$. oculata, $S$. variabilis and $E$. rostrata, are similar to those recorded for the New Zealand region, but the depth maxima for the former 2 species are somewhat deeper and shallower, respectively, than maxima recorded elsewhere (Freiwald et al. 2004, Lumsden et al. 2007). E. profunda, a congener of E. rostrata in the Atlantic Ocean, has a slightly shallower depth range than its related species in the New Zealand region (Freiwald et al. 2004, Lumsden et al. 2007). O. virgosa occurs most commonly at the same depths as the cold-water form of its Atlantic congener O. varicosa (Freiwald et al. 2004, Lumsden et al. 2007). However, in the New Zealand region, $O$. virgosa is also recorded from depths of nearly $800 \mathrm{~m}$. G. dumosa in the New Zealand region has the widest recorded depth range for this southern hemisphere-restricted species (Freiwald et al. 2004).

While Oculina virgosa was predominantly found on the shallow shelf and Goniocorella dumosa on slopes and rises, records for Enallopsammia rostrata, Solenosmilia variabilis and Madrepora oculata demonstrate a particular association with seamounts. These species are known to occur on seamounts elsewhere in the world (Rogers et al. 2007). Images from tow camera deployments on a number of seamounts in the New Zealand region confirm not only the occurrence of corals on these seafloor features, but their high abundance and the formation of reef-like structures, made by $S$. variabilis and $M$. oculata in particular, on the summits and upper slopes of even small seamounts or

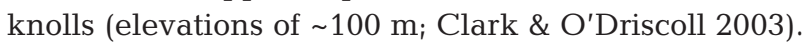
However, due to sampling bias, the apparent strength of the association between these stony coral species 
and seamounts may be an artefact. Predictive species distributional modelling is a means by which this apparent habitat association can be further examined.

\section{Environmental drivers of predicted distribution}

Previous research that directly examined the factors that may control the large-scale distribution of deepsea corals has identified measures of depth, temperature, current speed, oxygen, aragonite saturation state, dissolved inorganic carbon, nutrients, surface water chl a concentration or some other proxy for productivity regime as environmental drivers (Bryan \& Metaxas 2006, 2007, Davies et al. 2008, Tittensor et al. 2009, Woodby et al. 2009). Within these broad parameters suitable for corals to live, deep-sea corals are found to favour areas of complex topography, mainly on steep slopes and seamounts, where it is believed that the availability of suitable substrate and water currents strong enough to deliver or concentrate sufficient food for these suspension-feeding organisms is the principal reason for their more local distribution (Frederiksen et al. 1992, Mortensen \& Buhl-Mortensen 2004, White et al. 2005, Thiem et al. 2006, Mienis et al. 2007, Mortensen et al. 2008, Davies et al. 2009).

In accordance with previous studies, 3 of the 5 species (Madrepora oculata, Solenosmilia variabilis, Enallopsammia rostrata) were associated with low productivity, steep slopes, deep water and elevated topography such as seamounts. However, the association between the coral species and these environmental variables differed, i.e. the distribution of $S$. variabilis was mainly predicted by depth, E. rostrata by dissolved organic matter and particulate organic carbon flux and M. oculata by seamount occurrence and dissolved organic matter. In addition, the 2 variables associated with describing the regional oceanography (dynamic topography) and water mass (temperature residuals) predicted that all 3 species had broad geographic distributions that straddled both the subtropical and the subantarctic water masses. That these species of coral are also predicted to occur in areas with low surface water productivity presents an apparent paradox. However, the availability to corals of any food material derived from surface productivity depends upon the rate at which it is delivered to them. That is, the rate of vertical and near-bed horizontal particulate flux, the latter of which can be affected by topographically induced current flow regimes at slopes and seamounts.

The distributions of the 2 relatively shallow occurring species, Goniocorella dumosa and Oculina virgosa, had clearly different environmental associations relative to the other 3 species. G. dumosa was found at depths of $\sim 500 \mathrm{~m}$ and was associated with seamounts and steeply sloping areas. By contrast with the other species, G. dumosa occurred in areas where the primary productivity was slightly higher and waters slightly cooler relative to the previously mentioned species. Although only a few records were available for $O$. virgosa, the model identified the known distribution with a high level of accuracy. The distribution of O. virgosa was associated with much warmer waters than all previously discussed species, from shallow to steep slopes, where primary productivity varies from low to moderate and where tidal current speeds are relatively high. This species showed no clear association with depth and had only a slight tendency to be associated with seamounts.

Whilst measures of bottom current speed were identified as contributing to the model predictions of some species, the contribution was not particularly high. It is likely that measures of current speed, even though they were at higher resolutions than used in previous studies, were at a larger scale than the metre or possibly centimetre scale at which currents may influence the corals (Tittensor et al. 2009).

\section{Predicted geographic distribution in the New Zealand region}

The predictive maps of coral distribution suggest a high probability that Madrepora oculata occurs on isolated topographic features such as seamounts associated with the Kermadec and Three Kings Ridges, some areas of slopes on the Campbell and Bounty plateaux and the large Bollons Seamount, as well as other smaller seamount features scattered throughout the region. The model for Solenosmilia variabilis predicts that this species will have a more widespread distribution, with large areas of the Bounty Trough and deeper portions of the subantarctic slope of the Campbell Plateau, Bollons Seamount and the Kermadec Ridge having a high probability of occurrence in the southern part of the region. This species is also highly likely to occur on features associated with the Kermadec, Colville, Three Kings and West Norfolk Ridges, as well as the Lord Howe Rise and the northwest slopes of Challenger Plateau in the north of the region. The distribution model for the most commonly recorded species, Goniocorella dumosa, predicts that there is a high probability of occurrence at relatively shallow depths on the continental slopes of both main islands, along all of the Chatham Rise (in the vicinity of a subtropical front), on the rises of the Campbell and Bounty plateaux and Bollons Seamount. The modelled distribution map for Enallopsammia rostrata suggests that this species will be found along a relatively deep 
depth band on the slopes of the Campbell, Bounty and Challenger plateaux, and at similar depths on the Lord Howe Rise, and Macquarie, West Norfolk, Three Kings, Colville and Kermadec Ridges. This species is also predicted to occur on the Northland slope, western slope of the Bounty Trough and the eastern slope of the Chatham Rise. Seamount features throughout the region, including Bollons Seamount, are also sites with a high probability of $E$. rostrata occurrence. The area for which Oculina virgosa is predicted to have a high probability of occurrence is more geographically restricted than for the other habitat-forming stony corals species. This species has a high probability of being found along a narrow and relatively shallow depth band of the shelf in the northern part of the region. Areas around North Cape and East Cape are predicted to be particularly suitable for $O$. virgosa, as are small areas on the Kermadec and Three Kings Ridges and Lord Howe Rise.

\section{Model evaluation}

Our BRT models were successful at identifying the occurrence of the 5 study species, having an AUC of $>0.85$. As the goal of the modelling exercise was to produce spatial predictions, the model results give us an understanding of the potential environmental drivers at large spatial scales. An inability to predict the occurrence of some of the coral records probably highlights the absence of environmental, topographic or biological information at other spatial scales that might influence coral distributions. For example, Solenosmilia variablis and Madrepora oculata have been found on small patches $(<100 \mathrm{~m})$ of carbonate structure at cold seep sites off the east coast of the North Island (Baco et al. 2010), where the respective models indicated a low probability of occurrence. There are no suitably consistent maps of substratum type across the New Zealand region at the $\mathrm{km}$ scale, let alone at the sub-km scale, so it is not possible at present to determine the likely importance of substratum type on coral distribution.

In addition to the cross-validation procedures implicit in the BRT modelling, in order to provide confidence in the predictive distribution maps, it will be important in the future to undertake additional sampling for stony corals in the New Zealand region. The maps provide some obvious candidate sites for future sampling. During such sampling, environmental data should also be gathered at a scale that will allow for the prediction of coral distribution at smaller spatial scales (e.g. see Dolan et al. 2008, Guinan et al. 2009). In the meantime, our model maps are the best indicators of the distribution of 5 species of stony coral in the New Zealand region. They suggest that these species might have a wider ecological significance than previously thought, by providing habitat for other species over a range of geomorphic features and over potentially large areas. In addition, they confirm the strong association between some of the species and seamounts.

\section{Environmental management}

The results of our study have a number of implications for the effective management of the biodiversity of the New Zealand region. The improved data on geographic and depth distribution, and in particular the predicted distribution maps for the 5 habitat-forming coral species, can be used to assess the effectiveness of existing regional protection measures for biodiversity (as per Leathwick et al. 2008) and of the species as indicators of vulnerable marine ecosystem taxa (Parker et al. 2009). For example, the modelled data can be used to evaluate the spatial closures designed to protect seamount habitats from bottom fishing in the South Pacific Regional Fisheries Management Organisation (SPRFMO) area (Penney et al. 2009). Importantly, modelled distributions of the study taxa can now be used to help guide environmental management measures to mitigate current and likely future impacts upon seabed communities.

\section{Bottom trawling}

Given the established relationship between bottom trawling and the impact on habitat-forming corals and associated invertebrates (Koslow et al. 2001, Althaus et al. 2009, Clark \& Rowden 2009), and the past distribution of bottom trawling in the New Zealand region (Baird et al. 2010) in areas identified by the present study to be suitable habitat for habitat-forming corals, it is likely that trawling will already have had a widespread impact on benthic biodiversity. Nonetheless, the predicted distribution maps for the stony corals can be used by environmental managers and fishery stakeholders to avoid locations where any future bottom trawling is likely to impact the sensitive seafloor habitat and faunal communities. This might help prevent the high coral by-catch rates previously observed during the establishment of the orange roughy fishery (Anderson \& Clark 2003).

\section{Mineral exploration and exploitation}

Similarly, knowledge of the likely distribution of stony corals can be used to help mitigate the potential effects of mineral exploration and exploitation in the 
New Zealand region. Currently in the region, permits have been awarded to commercial companies to prospect or explore the potential for: (1) phosphorite nodule extraction from the Chatham Rise, a region with a high probability (0.8 to 1.0 ) of supporting the occurrence of Goniocorella dumosa; (2) the removal of seafloor massive sulphide deposits associated with seamounts on the Kermadec volcanic arc, features where Solenosmilia variabilis, Madrepora oculata and Enallopsammia rostrata have a high probability of occurring; and (3) oil and gas production from parts of the Bounty Trough and Campbell Plateau, areas that the models also reveal have a high probability of supporting populations of $S$. variabilis and E. rostrata.

\section{Climate change and ocean acidification}

Warming sea temperatures, changes in surface water productivity regimes and the alteration of current circulation patterns are among the climate change effects faced by the ocean as a consequence of rising atmospheric $\mathrm{CO}_{2}$ (Hoegh-Guldberg \& Bruno 2010). Such changes are considered likely to influence global distribution patterns of cold-water corals (Reyes Bonilla \& Cruz Piñón 2002). Our models indicate that any future changes in the aforementioned variables are likely to influence the distribution of the 5 habitat-forming stony coral species in the New Zealand region. Precisely how is unknown at present, but data layers are currently being developed that will allow the distributional effect of future climate scenarios to be determined for the study species in the region. Current global models that forecast the aragonite saturation horizon in the ocean indicate that it will shallow significantly in the next century due to ocean acidification (also a consequence of increasing atmospheric $\mathrm{CO}_{2}$ ) and thereby reduce the availability of suitable stony coral habitat (Guinotte et al. 2006). The recent global models of Tittensor et al. (2010) predict that suitable coral habitat will be particularly reduced in the NE Atlantic and in the New Zealand region. These models are at a relatively coarse spatial scale, and do not allow a management-scale appreciation of the potential changes across the region. The future development of more finely resolved aragonite saturation data layers (present and future) for the New Zealand region will allow our models to be re-run and the potential effect of ocean acidification on the distribution of cold-water stony corals, and implications of any change, to be assessed.

Acknowledgements. This study was part of the NIWA research programme 'Seamounts: their importance to fisheries and marine ecosystems' funded by the New Zealand Foundation for Research, Science and Technology (contract nos. CO1X0028, CO1X0224) with support from various contracts funded by the New Zealand Ministry of Fisheries (ZBD2000/04, ZBD2001/10, ZBD2004/01), whom we also thank for access to the observer and research databases. We also thank the Department of Conservation, who part-funded government observers for the collection of coral data (DOC 08309/DOC09305). At NIWA, we thank E. MacKay for drawings of the study species; M. Hadfield, R. Gorman, F. Oehler and $M$. Pinkerton for providing environmental data and comments; and particularly J. Leathwick (now at the Department of Conservation, New Zealand) for preliminary BRT models and for subsequent modelling guidance and advice. M. Clark provided overall support for this research initiative, and critical comments from D. Bowden improved a draft version of the paper. The constructive comments of 3 reviewers were also helpful. The preliminary results of this research were presented at the 4th Deep-Sea Coral Symposium (Wellington, New Zealand) in 2008 (Miller et al. 2009).

\section{LITERATURE CITED}

Adkins JF, Henderson GM, Wang SL, O'Shea S, Mokadem F (2004) Growth rates of the deep-sea scleractinia Desmophyllum cristagalli and Enallopsammia rostrata. Earth Planet Sci Lett 227:481-490

Althaus F, Williams A, Schlacher TA, Kloser RK and others (2009) Impacts of bottom trawling on deep-coral ecosystems of seamounts are long-lasting. Mar Ecol Prog Ser 397:279-294

Anderson OF, Clark MR (2003) Analysis of bycatch in the fishery for orange roughy Hoplostethus atlanticus, on the South Tasman Rise. Mar Freshw Res 54:643-652

Araújo MB, Guisan A (2006) Five (or so) challenges for species distribution modelling. J Biogeogr 33:1677-1688

Auster PJ, Moore J, Heinonen KB, Watling L (2005) A habitat classification scheme for seamount landscapes: assessing the functional role of deep-water corals as fish habitat. In: Freiwald A, Roberts JM (eds) Cold-water corals and ecosystems. Springer-Verlag, Berlin, Heidelberg, p 761-769

Baco AR, Rowden AA, Levin LA, Smith CR, Bowden DA (2010) Initial characterization of cold seep faunal communities on the New Zealand Hikurangi margin. Mar Geol 272:251-259

Baird SJ, Wood BA, Bagley NW (2011) Nature and extent of commercial fishing effort on or near the seafloor within the New Zealand 200 n. mile Exclusive Economic Zone, 1989-90 to 2004-05. N Z Aquatic Environment and Biodiversity Report No. 73. New Zealand Ministry of Fisheries, Wellington

> Behrenfeld MJ, Falkowski PG (1997) Photosynthetic rates derived from satellite-based chlorophyll concentration. Limnol Oceanogr 42:1-20

Beyer HL (2004) Hawth's analysis tools for ArcGIS. Available at www.spatialecology.com/htools

Bryan TL, Metaxas A (2006) Distribution of deep-water corals along the North American continental margins: relationships with environmental factors. Deep-Sea Res I 53: 1865-1879

Bryan TL, Metaxas A (2007) Predicting suitable habitat for deep-water gorgonian corals on the Atlantic and Pacific Continental Margins of North America. Mar Ecol Prog Ser 330:113-126

Buhl-Mortensen L, Mortensen PB (2005) Distribution and diversity of species associated with deep-sea gorgonian corals off Atlantic Canada. In: Freiwald A, Roberts JM (eds) Cold-water corals and ecosystems. Springer-Verlag, Heidelberg, p 849-879 
Burgess SN (2002) Environmental and ecological aspects of deep-sea scleractinians in the New Zealand region. MSc thesis, University of Auckland

Cairns SD (1982) Antarctic and subantarctic Scleractinia. Antarc Res Ser 34

Cairns SD (1984) New records of ahermatypic corals (Scleractinia) from the Hawaiian and Line Islands. Occas Pap Bishop Mus 25:1-30

Cairns SD (1995) The marine fauna of New Zealand: Scleractinia (Cnidaria: Anthozoa). N Z Oceanogr Inst Mem 103: $1-210$

Cairns SD (2007) Deep-water corals: an overview with special reference to diversity and distribution of deep-water scleractinian corals. Bull Mar Sci 81:311-322

Caldeira K, Wickett ME (2003) Anthropogenic carbon and ocean $\mathrm{pH}$. Nature 425:365

CANZ (Charting Around New Zealand) (2008) New Zealand regional bathymetry, 1:4000000, 2nd edn. CANZ Misc Ser No 85. NIWA, Wellington

Clark MR, O'Driscoll RL (2003) Deepwater fisheries and their impacts on seamount habitat in New Zealand. J Northwest Atl Fish Sci 31:441-458

Clark MR, Rowden AA (2009) Effect of deepwater trawling on the macro-invertebrate assemblages of seamounts on the Chatham Rise, New Zealand. Deep-Sea Res I 56:1540-1544

Clark MR, Tittensor DP (2010) An index to assess the risk to stony corals from bottom trawling on seamounts. Mar Ecol 31(Suppl 1):200-211

Clark MR, Wright I, Wood B, O'Shea S, McKnight D (1999) New research on seamounts. Seafood New Zealand $7(1)$ : 31-34

Consalvey M, MacKay K, Tracey D (2006) Information review for protected deep-sea coral species in the New Zealand region. NIWA Client Report WLG2006-85 prepared for Department of Conservation. NIWA, Wellington

Costello MJ, McCrea M, Freiwald A, Lundalv T and others (2005) Role of cold-water Lophelia pertusa coral reefs as habitat in the NE Atlantic. In: Freiwald A, Roberts JM (eds) Cold-water corals and ecosystems. Springer-Verlag, Berlin, p 771-805

Davies AJ, Wisshak M, Orr JC, Roberts JM (2008) Predicting suitable habitat for the cold-water coral Lophelia pertusa (Scleractinia). Deep-Sea Res I 55:1048-1062

Davies AJ, Duineveld, GCA, Lavaleye MSS, Bergman MJN, van Haren H, Roberts JM (2009) Downwelling and deepwater bottom currents as food supply mechanisms to the cold-water coral Lophelia pertusa (Scleractinia) at the Mingulay Reef complex. Limnol Oceanogr 54:620-629

Dawson EW (1984) The benthic fauna of the Chatham Rise: an assessment relative to possible effects of phosphorite mining. Geol Jahrb D65:213-235

De'ath G (2007) Boosted trees for ecological modeling and prediction. Ecology 88:243-251

Dodds LA, Roberts JM, Taylor AC, Marubini (2007) Metabolic tolerance of the cold-water coral Lophelia pertusa (Scleractinia) to temperature and dissolved oxygen change. J Exp Mar Biol Ecol 349:205-214

- Dolan MFJ, Grehan AJ, Guinan JC, Brown C (2008) Modelling the local distribution of cold-water corals in relation to bathymetric variables: adding spatial context to deep-sea video data. Deep-Sea Res I 55:1564-1579

D'Onghia G, Maiorano P, Sion Giove LA, Capezzuto FR, Carlucci R, Tursi A (2010) Effects of deep-water coral banks on the abundance and size structure of the megafauna in the Mediterranean Sea. Deep-Sea Res II 57:397-411

> Duineveld GCA, Lavaleye MSS, Berghuis EM (2004) Particle flux and food supply to a seamount cold-water coral com- munity Galicia Bank, NW Spain. Mar Ecol Prog Ser 277: $13-23$

Duineveld GCA, Lavaleye MSS, Bergman MJN, de Stigter H, Mienis F (2007) Trophic structure of a coldwater coral mound community (Rockall Bank, NE Atlantic) in relation to the near-bottom particle supply and current regime. Bull Mar Sci 81:449-467

Elith J, Graham CH, Anderson RP, Dudik M and others (2006) Novel methods improve prediction of species' distributions from occurrence data. Ecography 29:129-151

Elith J, Leathwick JR, Hastie T (2008) A working guide to boosted regression trees. J Anim Ecol 77:802-813

Etnoyer P, Morgan LE (2005) Habitat forming deep-sea corals in the Northeast Pacific Ocean. In: Freiwald A, Roberts JM (eds) Cold-water corals and ecosystems. Springer-Verlag Berlin, p 332-343

Fossa JH, Mortensen PB, Furevik DM (2002) The deep-water coral Lophelia pertusa in Norwegian waters: distribution and fishery impacts. Hydrobiologia 471:1-12

Frederiksen R, Jensen A, Westerberg H (1992) The distribution of the scleractinian coral Lophelia pertusa around the Faroe Islands and the relation to internal tidal mixing. Sarsia 77:157-171

Freiwald A, Fosså JH, Grehan A, Koslow JA, Roberts JM (2004) Cold-water coral reefs: out of sight no longer out of mind. United Nations Environment Programme - World Conservation Monitoring Centre, Cambridge

Gass SE, Robert JM (2006) The occurrence of the cold-water coral Lophelia pertusa (Scleractinia) on oil and gas platforms in the North Sea: colony growth, recruitment and environmental controls on distribution. Mar Pollut Bull 52: 549-559

Genin A, Noble M, Lonsdale PF (1989) Tidal currents and anticyclonic motions on two North Pacific seamounts. Deep-Sea Res 36:1803-1815

Gorman RM, Bryan KR, Laing AK (2003) A wave hindcast for the New Zealand region deep water wave climate. N Z J Mar Freshw Res 37:589-612

> Guinan J, Grehan AJ, Dolan MFJ, Brown C (2009) Quantifying relationships between video observations of coldwater coral cover and seafloor features in Rockall Trough, west of Ireland. Mar Ecol Prog Ser 375:125-138

> Guinotte JM, Orr J, Cairns S, Freiwald A, Morgan L, George R (2006) Will human induced changes in seawater chemistry alter the distribution of deep-sea scleractinian corals? Front Ecol Environ 4:141-146

> Guisan A, Lehmann A, Ferrier S, Austin M, Overton JMCC, Aspinall R, Hastie T (2006) Making better biogeographical predictions of species distributions. J Appl Ecol 43: 386-392

Hadfield M, Uddstrom M, Goring D, Gorman R and others (2002) Physical variables for the New Zealand Marine Environment Classification System: development and description of data layers. NIWA Client Report CHC2002043. NIWA, Wellington

Hall-Spencer JV, Allain V, Fossa JH (2002) Trawling damage to Northeast Atlantic ancient coral reefs. Proc R Soc Lond Ser B Biol Sci 269:507-511

> Hanley JA, McNeil BJ (1982) The meaning and use of the area under a receiver operating characteristic (ROC) curve. Radiology 143:29-36

Heifetz J (2002) Coral in Alaska: distribution, abundance, and species associations. Hydrobiologia 471:19-28

- Henry LA, Roberts JM (2007) Biodiversity and ecological composition of macrobenthos on cold-water coral mounds and adjacent offmound habitat in the bathyal Porcupine Seabight, NE Atlantic. Deep-Sea Res I 54:654-672 
Hoegh-Guldberg O, Bruno JF (2010) Impact of climate change on the world's marine ecosystems. Science 328:1523-1528

Hoernle K, Mortimer N, Werner R, Hauff F (eds) (2003) FS/RV Sonne Fahrtbericht SO168 (Cruise Report S0168) Zealandia. Causes and effects of plume and rift-related cretaceous and cenozoic volcanism on Zealandia. Geomar Rep 113:1-127

Hourigan TF, Boutillier J, Clark M, Hall-Spencer J and others (2008) The status of cold-water coral communities of the world: a brief update. In: Wilkinson C (ed) Status of coral reefs of the world: 2008. Global Coral Reef Monitoring Network, Townsville, p 57-66

Huehnerbach V, Blondel P, Huvenne V, Freiwald A (2007) Habitat mapping on a deep-water coral reef off Norway, with a comparison of visual and computer-assisted sonar imagery interpretation. In: Todd B, Greene G (eds) Mapping the seafloor for habitat characterization. Geol Assoc Can Spec Pap 47:297-308

Husebø A, Nøttestad L, Fosså JH, Furevik DM, Jørgensen SB (2002) Distribution and abundance of fish in deep-sea coral habitats. Hydrobiologia 471:91-99

Jensen A, Frederiksen R (1992) The fauna associated with the bankforming deepwater coral Lophelia pertusa (Scleractinaria) on the Faroe shelf. Sarsia 77:53-69

> Jonsson LG, Nilsson PG, Floruta F, Lundälv T (2004) Distributional patterns of macro- and megafauna associated with a reef of the cold-water coral Lophelia pertusa on the Swedish west coast. Mar Ecol Prog Ser 284:163-171

Kogan I, Paull CK, Kuhnz L, Burton EJ, Von Thun S, Greene HG, Barry JP (2003) Environmental impact of the ATOC/Pioneer seamount submarine cable. Report prepared by the Monterey Bay Aquarium Research Institute (MBARI) in partnership with the National Oceanic and Atmospheric Administration - Oceanic and Atmospheric Research (NOAA-OAR) and National Ocean Service (NOAA-NOS). Available at http://montereybay.noaa.gov/ research/techreports/cablesurveynov2003.pdf

Koslow JA, Gowlett-Holmes K, Lowry JK, O'Hara T, Poore GCB, Williams A (2001) Seamount benthic macrofauna off southern Tasmania: community structure and impacts of trawling. Mar Ecol Prog Ser 213:111-125

Leathwick JR, Elith J, Francis MP, Hastie T, Taylor P (2006) Variation in demersal fish species richness in the oceans surrounding New Zealand: an analysis using boosted regression trees. Mar Ecol Prog Ser 321:267-281

> Leathwick JR, Elith J, Chadderton WL, Rowe R, Hastie T (2008) Dispersal, disturbance and the contrasting biogeographies of New Zealand's diadromous and nondiadromous fish species. J Biogeogr 35:1481-1497

Levin LA, Etter RJ, Rex MA, Gooday AJ and others (2001) Environmental influences on regional deep-sea species diversity. Annu Rev Ecol Syst 32:51-93

Lumsden E, Hourigan TF, Bruckner AW, Dorr G (eds) (2007) The state of deep coral ecosystems of the United States. NOAA Tech Memo CRCP-3, Silver Spring, MD

Lutz MJ, Caldeira K, Dunbar RB, Behrenfeld MJ (2007) Seasonal rhythms of net primary production and particulate organic carbon flux to depth describe the efficiency of biological pump in the global ocean. J Geophys Res Oceans 112:C10011 doi: 10.1029/2006JC003706

Maier C, Hegeman J, Weinbauer MG, Gattuso JP (2009) Calcification of the cold-water coral Lophelia pertusa under ambient and reduced pH. Biogeosci Discuss 6:1875-1901

> Mastrototaro F, D'Onghia G, Corriero G, Matarrese A and others (2010) Biodiversity of the white coral bank off Cape Santa Maria di Leuca (Mediterranean Sea): an update. Deep-Sea Res II 57:412-430
McCloskey LR (1970) The dynamics of the community associated with a marine scleractinian coral. Int Rev Ges Hydrobiol 55:13-81

McKnight DG, Estcourt IN (1978) Benthic ecology of Caswell and Nancy Sounds. In: Glasby GP (ed) Fiord studies: Caswell and Nancy Sounds, New Zealand. N Z Oceanogr Inst Mem 79:85-90

Mienis F, de Stigter HC, White M, Duineveld G, de Haas H, van Weering TCE (2007) Hydrodynamic controls on coldwater coral growth and carbonate-mound development at the SW and SE Rockall trough Margin, NE Atlantic Ocean. Deep-Sea Res I 54:1655-1674

Miller K, Tracey D, Neil H (eds) (2009) Theme Section. Conservation and management of deep-sea corals and coral reefs. Mar Ecol Prog Ser 397:1-360

> Moore J, Auster P, Calini D, Heinonen K, Barber K, Hecker B (2008) The false boarfish Neocyttus helgae in the western North Atlantic. Bull Peabody Mus Nat Hist 49:31-41

Morgan LE, Etnoyer P, Scholz AJ, Mertens M, Powell M (2005) Conservation and management implications of deep-sea coral distributions and fishing effort in the northeast Pacific Ocean. In: Freiwald A, Roberts JM (eds) Deepwater corals and ecosystems. Springer-Verlag, Heidelberg, p 1171-1187

> Mortensen PB, Buhl-Mortensen L (2004) Distribution of deepwater gorgonian corals in relation to benthic habitat features in the Northeast Channel (Atlantic Canada). Mar Biol 144:1223-1238

Mortensen PB, Hovland MT, Fossa JH, Furevik DM (2001) Distribution, abundance and size of Lophelia pertusa coral reefs in mid-Norway in relation to seabed characteristics. J Mar Biol Assoc UK 81:581-597

Mortensen PB, Buhl-Mortensen L, Gebruk AV, Krylovab EM (2008) Occurrence of deep-water corals on the MidAtlantic Ridge based on MAR-ECO data. Deep-Sea Res II 55:142-152

Nelson WA, Gordon DP (1997) Assessing New Zealand's marine biological diversity - a challenge for policy makers and systematists. N Z Sci Rev 54:58-66

Parker SJ, Penney AJ, Clark MR (2009) Detection criteria for managing trawl impacts on vulnerable marine ecosystems in high seas fisheries of the South Pacific Ocean. Mar Ecol Prog Ser 397:309-317

Penney AJ, Parker SJ, Brown JH (2009) Protection measures implemented by New Zealand for vulnerable marine ecosystems in the South Pacific Ocean. Mar Ecol Prog Ser 397:341-354

> Phillips SJ, Anderson RP, Schapire RE (2006) Maximum entropy modeling of species geographic distributions. Ecol Model 190:231-259

Phillips SJ, Dudik M, Elith J, Graham CH, Lehmann A, Leathwick J, Ferrier S (2009) Sample selection bias and presence-only distribution models: implications for background and pseudo-absence data. Ecol Appl 19:181-197

> Pinkerton MH, Moore GF, Lavender SJ, Gall MP and others (2006) A method for estimating inherent optical properties of New Zealand continental shelf waters from satellite ocean colour measurements. N Z J Mar Freshw Res 40: 227-247

Ralph PM, Squires DF (1962) The extant scleractinian corals of New Zealand. Zool Publ Vic Univ Wellington 29:1-19

Reed JK, Koenig CC, Shepard AN (2007) Impacts of bottom trawling on a deep-water Oculina coral ecosystem off Florida. Bull Mar Sci 81:481-496

Reveillaud J, Freiwald A, Van Rooij D, Le Guilloux E and others (2008) The distribution of scleractinian corals in the Bay of Biscay, NE Atlantic. Facies 54:317-331 
Reyes Bonilla H, Cruz Piñón G (2002) Influence of temperature and nutrients on species richness of deep water corals from the western coast of the Americas. Hydrobiologia 471:35-41

Ridgeway G (2006) 'gbm' generalized boosted regression models, R Package Version 1.5. Available at www.marine. csiro.au/ dunn/cars2009, accessed July 2008

Roberts JM, Wheeler AJ, Freiwald A (2006) Reefs of the deep: the biology and geology of cold-water coral ecosystems. Science 312:543-547

Roberts JM, Henry LA, Long D, Hartley JP (2008) Cold-water coral reef frameworks, megafaunal communities and evidence for coral carbonate mounds on the Hatton Bank, north east Atlantic. Facies 54:297-316

Roberts JM, Wheeler AJ, Freiwald A, Cairns S (2009) Coldwater corals. The biology and geology of deep-sea coral habitats. Cambridge University Press, Cambridge

Roberts S, Hirshfield M (2004) Deep-sea corals: out of sight, but no longer out of mind. Front Ecol Environ 2:123-130

Rogers AD (1999) The biology of Lophelia pertusa (Linnaeus 1758) and other deep-water reef forming corals and impacts from human activities. Int Rev Hydrobiol 84: 315-406

Rogers AD, Baco A, Griffiths H, Hall-Spencer JM (2007) Corals on seamounts. In: Pitcher TJ, Hart PJB, Morato T, Santos R, Clark M (eds) Seamounts: ecology, fisheries and conservation. Blackwell Publishing Fisheries and Aquatic Resources Series. Blackwell Scientific, Oxford, p 141-169

Rowden AA, Clark M (2004) Uncovering secrets of our seamounts. Water Atmos 12:22-23

Rowden AA, Oliver M, Clark MR, Mackay K (2008) New Zealand's 'SEAMOUNT' database: recent updates and its potential use for ecological risk assessment. N Z Aquatic Environment and Biodiversity Report, No. 27. New Zealand Ministry of Fisheries, Wellington

Sanchez JA (2005) Systematics of the bubblegum corals (Cnidaria: Octocorallia: Paragorgiidae) with description of new species from New Zealand and the Eastern Pacific. Zootaxa 1014

Squires DF (1965) Deep-water coral structure on the Campbell Plateau, New Zealand. Deep-Sea Res 12:785-788

Squires DF, Keyes IW (1967) The marine fauna of New Zealand: scleractinian corals. N Z Dep Sci Ind Res Bull 185: $1-46$

Editorial responsibility: Paul Snelgrove, St. John's, Newfoundland, Canada
Stone RP (2006) Coral habitat in the Aleutian Islands of Alaska: depth distribution, fine-scale species associations, and fisheries interactions. Coral Reefs 25:229-238

> Thiem Ø, Ravagnan E, Fosså JH, Bersten J (2006) Food supply mechanisms for coldwater corals along a continental shelf edge. J Mar Syst 60:207-219

> Tittensor DP, Baco-Taylor AR, Brewin P, Clark MR and others (2009) Predicting global habitat suitability for stony corals on seamounts. J Biogeogr 36:1111-1128

Tittensor DP, Baco AR, Hall-Spencer JM, Orr JC, Rogers AD (2010) Seamounts as refugia from ocean acidification for cold-water stony corals. PSZN I: Mar Ecol 31(Suppl 1): $212-225$

Tracey DM, Anderson OF, Naylor JR (2007) A guide to common deepsea invertebrates in New Zealand waters. N Z Aquatic Environment and Biodiversity Report No. 10.

Turley CM, Roberts JM, Guinotte JM (2007) Corals in deepwater: Will the unseen hand of ocean acidification destroy cold-water ecosystems? Coral Reefs 26:445-448

Uddstrom, MJ, Oien, NA (1999) On the use of high resolution satellite data to describe the spatial and temporal variability of sea surface temperatures in the New Zealand region. J Geophys Res 104:20729-20751

Waller R, Watling L, Auster P, Shank T (2007) Anthropogenic impacts on the Corner Rise Seamounts, NW Atlantic Ocean. J Mar Biol Assoc UK 87:1075-1076

> Walters RA, Goring DG, Bell RG (2001) Ocean tides around New Zealand. N Z J Mar Freshw Res 35:567-579

- Wheeler AJ, Beyer A, Freiwald A, de Haas $\mathrm{H}$ and others (2007) Morphology and environment of cold-water coral carbonate mounds on the NW European margin. Int J Earth Sci 96:37-56

White M, Mohn C, de Stigter H, Mottram G (2005) Deepwater coral development as a function of hydrodynamics and surface productivity around submarine banks of the Rockall Trough, NE Atlantic. In: Freiwald A, Roberts JM (eds) Cold-water corals and ecosystems. Springer-Verlag, Berlin, p 503-514

> Woodby D, Carlile D, Hulbert L (2009) Predictive modeling of coral distribution in the Central Aleutian Islands, USA. Mar Ecol Prog Ser 397:227-240

Zibrowius H (1980) Les scléractiniaires de la Méditerranée et de l'Atlantique nord-oriental. Mem Inst Oceanogr (Monaco) 11:1-226

Submitted: December 12, 2010; Accepted: April 7, 2011

Proofs received from author(s): May 23, 2011 